\title{
Article \\ Understanding the Responses of Soil Bacterial Communities to Long-Term Fertilization Regimes Using DNA and RNA Sequencing
}

\author{
Juan $\mathrm{Li}^{+}\left(\mathbb{D}\right.$, Yanchen Wen ${ }^{+}$and Xiangdong Yang * (D) \\ Key Laboratory of Plant Nutrition and Fertilizer, Ministry of Agriculture and Rural Affairs/Institute of \\ Agricultural Resources and Regional Planning, Chinese Academy of Agricultural Sciences, Beijing 100081, China; \\ lijuan02@caas.cn (J.L.); wenyanchen@caas.cn (Y.W.) \\ * Correspondence: yangxiangdong@caas.cn; Tel.: +86-10-82109614 \\ † Juan Li and Yanchen Wen contributed equally to this work.
}

Citation: Li, J.; Wen, Y.; Yang, X.

Understanding the Responses of Soil Bacterial Communities to Long-Term Fertilization Regimes Using DNA and RNA Sequencing. Agronomy 2021, 11, 2425. https://doi.org/10.3390/ agronomy 11122425

Academic Editor: Helena Freitas

Received: 23 October 2021

Accepted: 25 November 2021

Published: 28 November 2021

Publisher's Note: MDPI stays neutral with regard to jurisdictional claims in published maps and institutional affiliations.

Copyright: (c) 2021 by the authors. Licensee MDPI, Basel, Switzerland. This article is an open access article distributed under the terms and conditions of the Creative Commons Attribution (CC BY) license (https:// creativecommons.org/licenses/by/ $4.0 /)$.

\begin{abstract}
Studies of soil DNA-based and RNA-based bacterial communities under contrasting longterm fertilization regimes can provide valuable insights into how agricultural management affects soil microbial structure and functional diversity. In this study, soil bacterial communities subjected to six fertility treatments in an alkaline soil over 27 years were investigated by 454 pyrosequencing based on 16S rDNA and 16S rRNA. Long-term fertilization showed significant influences on the diversity of the soil DNA-based bacteria, as well as on their RNA-based members. The top five phyla (Proteobacteria, Acidobacteria, Chloroflexi, Actinobacteria, and Planctomycetes) were found in both the DNA- and RNA-based samples. However, the relative abundances of these phyla at both DNA and RNA levels were showed significantly different. Analysis results showed that the diversity of the $16 \mathrm{~S}$ rRNA samples was consistently lower than that of the rDNA samples, however, 16S rRNA samples had higher relative abundance. PICRUSt analysis indicated that glycan biosynthesis and metabolism were detected mainly in the DNA samples, while metabolism and degradation of xenobiotics and the metabolism of amino acids, terpenoids and polyketides were relatively higher in the RNA samples. Bacilli were significantly more abundant in all the OM-fertilized soils. Redundancy analysis indicated that the relative abundances of both DNA- and RNA-based bacterial groups were correlated with soil total organic carbon content, nitrogen content, Olsen-P, and soil pH. Moreover, the RNA-based Bacilli were positively correlated with available phosphorus (Olsen-P).
\end{abstract}

Keywords: bacterial community; diversity; 16S rDNA and 16S rRNA sequencing; long-term fertilization regime; labile organic carbon fractions

\section{Introduction}

The challenge of meeting the food consumption needs of a growing global populationwhile reducing the environmental impact of agriculture-has led to the emergence of the sustainable intensification paradigm, which aims to balance these two needs without the conversion of additional non-agricultural land [1]. Increasing food production without overusing mineral fertilizers - and the associated negative environmental impacts-will require optimal management strategies that improve the efficiency of fertilizer use, particularly in China where excessive precautionary amounts of fertilizers have traditionally been used to ensure maximum yields [2,3]. Previous reports have indicated that strategies in England and the EU encouraging well-managed animal manure application led to more environmentally sensitive farming methods, with reduced usage of mineral fertilizers [4,5]. China has also strived to improve the use of OM as a nutrient source in its recent efforts to sustainably intensify agriculture [6]. It is therefore essential to understand the relationships between fertilizer management, agricultural production, and agroecosystem processes to guide future sustainable intensification strategies. 
Soil ecosystems harbor the most diverse microbial communities on Earth, with tens of thousands of taxa [7]. Distinctive taxa, and changes in their relative distribution under different agricultural practices, have been previously investigated [8]. Case reports have indicated that soil microbial biomass, diversity and activity can be altered by changes in the fertilization regime [3,9]. These differences were mainly attributed to variations in the levels of soil nitrogen, carbon, and $\mathrm{pH}$ among fertilization systems [10]. Soil microbial diversity can be decreased by long-term mineral fertilizer addition [11,12]; microbial diversity, evenness, and composition can also be changed by OM amendment $[13,14]$, but not always in a consistent manner. For instance, an increase in soil microbial diversity and evenness has been observed under long-term OM application [15], yet in other studies soil bacterial diversity decreased-compared to conventional farming-under organic management practices [16]. Differences in microbial community structure may be due to the effects of fertilizers on labile soil organic matter fractions [17]. Ramírez et al. [18] demonstrated that microbial diversity and composition respond to labile soil organic carbon (SOC) fractionssuch as light fraction organic matter (LFOM) and the ratio of permanganate oxidizable carbon to SOC - across a wide range of environmental conditions. Soil bacterial diversity increased with microbial biomass $C$ (Cmic), and that variations in extracellular enzyme activities were strongly correlated with dissolved organic carbon (DOC) [19]. The change in coarse unprotected particulate organic matter (cPOM) has also been indicated to be an important factor affecting soil microbial community (microbiome) composition [20].

Soil microorganisms play crucial roles in essential agroecosystem functions and services, including contributing to and mitigating greenhouse gas emissions, controlling soil nutrient status - via $\mathrm{N}$ and $\mathrm{P}$ immobilization and mineralization-and decontamination of environmental pollutants [14,21]. Changes in soil microbiome composition can benefit soil biogeochemical processes and ecosystem services; a recent meta-analysis demonstrated how OM increases crop yields by improving microbe-mediated soil functioning [3]. Scientists strive to design soil management systems that maximize microbiome function, to counteract threats to agricultural production from climate change, and limited supply (and the environmental cost) of mineral fertilizers [22]. Consequently, understanding the extent to which soil microbial communities control soil biogeochemical processes and ecosystem functions is critical to the design of improved agroecosystems [23,24]. RNA (both rRNA and mRNA) was used as a better indicator of active microbial populations and the comparison of DNA and RNA-based bacteria is of great importance to elucidate metabolic activity level of the microbial taxa represented in DNA-based sequencing studies [25,26]. Scientists have also used the combined rDNA/rRNA method under various management regimes-such as long-term experimental $\mathrm{N}$ deposition [27], artificial warming and grazing [28]. In this way, the combined DNA- and RNA-derived evaluations of bacteria can provide a deeper understanding of bacterial community dynamics [29]. Previous results have showed a significant difference between the resident (DNA) and active (RNA) microbial communities [25]. The active microbial populations obtained by RNA analysis exhibit similar diversity as DNA-derived populations in a Picea abies forest topsoil, but significantly differ in the composition of microbial taxa and several highly active taxa show low abundance or even absence in the DNA pool [30]. Therefore, tracing the responses of soil bacteria to long-term fertilization regimes using DNA and RNA sequencing can help us understand how engineered ecosystems (e.g., fertilized fields) impact the distribution and functioning of soil bacteria.

The North China Plain (NCP) is a typical cropland with wheat and maize doublecropping system, producing $1 / 2$ wheat and $1 / 3$ maize of China [31,32]. The ability to meet the future goal of increased crop yield in this area may hinge on optimizing the soil-crop microbiota and improving nutrient use efficiency. Long-term fertilization experiments (>25 years) can depict soil-crop ecosystems that are in a steady state. Understanding fertility management's impacts on bacterial diversity and activity will help us determine which soil nutrient dynamic processes are affected by management, thus facilitating the design of management systems that enhance beneficial processes while minimizing the 
negative. To address these objectives, we used 16S rDNA and 16S rRNA sequencing from $\mathrm{NCP}$ soils of a 27-year winter wheat-summer maize rotation long-term fertilization trial. We examined the soil DNA-based and RNA-based bacterial communities and identified gene transcription behaviors-associated with response and adaptation to different longterm fertility treatments - of individual organisms. With this approach, we aimed to test the following hypotheses: (1) Long-term fertilization regimes show significant effects on DNAand RNA-derived soil bacteria. (2) There are significant differences between DNA-based soil bacterial communities and RNA-based members. (3) Specific RNA-based bacterial taxa respond differently to different fertility treatments.

\section{Material and Methods}

\subsection{Experimental Design}

The long-term fertilizer trial was initiated in 1986 in Yucheng City, Shandong Province in NCP, China $\left(116^{\circ} 34 \mathrm{E}, 36^{\circ} 50 \mathrm{~N}\right)$. The mean annual temperature is $13.4^{\circ} \mathrm{C}$ and the average annual precipitation is $69 \mathrm{~mm}$. The soil physicochemical properties $(0-20 \mathrm{~cm})$ in the beginning were organic carbon $3.93 \mathrm{~g} \mathrm{~kg}^{-1}$, total nitrogen $0.51 \mathrm{~g} \mathrm{~kg}^{-1}$, available $\mathrm{P}$ $7.50 \mathrm{mg} \mathrm{kg}^{-1}$, available $\mathrm{K} 73.00 \mathrm{mg} \mathrm{kg}^{-1}$, CEC $15.84 \mathrm{cmol} \mathrm{kg}^{-1}$ and $\mathrm{pH}$ value 8.56 . The soil type is fluvo-aquic and light loam.

This trial was established with six treatments (four replicates per treatment) of $28 \mathrm{~m}^{2}$ $(4 \mathrm{~m} \times 7 \mathrm{~m})$ for each. The treatments included: no fertilizer input (CK); treatment with mineral fertilizer input (SF) and treatment with cattle manure input (SM); a treatment with half mineral fertilizer input plus half manure applied (FM); a treatment with double amount of mineral fertilizer input (DF); and a treatment with double amount of cattle manure input (DM). All treatments were arranged randomly. The manure applications were estimated according to the $\mathrm{N}$ content of the manure. The fertilizer quantity and the time of treatment were as described by Li et al. [19]. Briefly, typical compost nutrients of cattle manure were $\sim 1.84 \% \mathrm{~N}, \sim 1.02 \% \mathrm{P}_{2} \mathrm{O}_{5}$, and $\sim 1.15 \% \mathrm{~K}_{2} \mathrm{O}$. In addition, $\mathrm{N}$ (urea), $\mathrm{P}_{2} \mathrm{O}_{5}$ (mono-calcium phosphate) and $\mathrm{K}_{2} \mathrm{O}$ (potassium sulfate) of fertilizer application amount was 375 450, 225 300 and $150 \mathrm{~kg} \mathrm{ha}^{-1}$ each year, the cattle manure and chemical fertilizer $\mathrm{P}, \mathrm{K}$ were conducted once before wheat sowing. $40 \%$ urea was applied before sowing and $60 \%$ for tillering stage both for winter wheat and summer maize.

\subsection{Soil Sampling}

Soil samples (the top $20 \mathrm{~cm}$ ) were collected with an auger in October 2013 after maize harvest by taking 5 random cores to form a composite sample and then were conserved in an ice box and separated into four parts: (1) One part was used immediately for $\mathrm{NO}_{3}{ }^{-} \mathrm{N}$ measurement with extraction of $2 \mathrm{M} \mathrm{KCl}$ using the flow injection auto-analyzer (AA3, Bran-Luebbe, Germany) (Table S1). (2) The second part was air-dried to determine the TN, SOC, TP, Olsen-P, available K, and pH as described by Li et al. [33] (Table S1). (3) The third part was stored at $-80^{\circ} \mathrm{C}$ for DNA sequencing. (4) The last one was stored in a $2 \mathrm{~mL}$ centrifugal tube with RNAlater (Qiagen, Germany) at $-20^{\circ} \mathrm{C}$ for RNA extraction.

The analysis of $C$ addition - organic manure-C (MA-C), rhizodeposition- $C$, stubble- $C$, and root- $\mathrm{C}$ - and the analysis of labile $\mathrm{SOC}$ fractions - mineralizable $\mathrm{C}(\mathrm{Cmin})$, microbial $\mathrm{C}(\mathrm{MBC})$, dissolved OC (DOC), particulate OC (POC), light fraction OC (LFOC), and permanganate oxidizable $\mathrm{C}\left(\mathrm{KMnO}_{4}-\mathrm{C}\right)$ - have been described by Li et al. [33].

\subsection{Microbial DNA Extraction, RNA Isolation and $C D N A$ Synthesis, PCR Amplification}

Total DNA was extracted by using the E.Z.N.A. ${ }^{\circledR}$ Soil DNA Kit (Omega Bio-tek, Norcross, GA, USA). The quality and concentration of the DNA extracts were detected by $1.2 \%$ agarose gel electrophoresis and NanoDrop 2000 (Wilmington, DE, USA), and then stored in $-80{ }^{\circ} \mathrm{C}$ freezer.

RNA was extracted as previously reported [34,35], with minor modifications. DNA of the extract was digested using recombinant DNase I (Takara) and then the RNA extract was purified. PCR amplifications were carried out using universal $16 \mathrm{~S}$ rDNA primers 
(27F, 533R), with purified RNA as a template to exclude DNA contamination. The quality and abundance of RNA were assessed by $1 \%$ agarose gel electrophoresis and NanoDrop 2000. The purified RNA was converted to complementary DNA (cDNA) and then stored at $-80^{\circ} \mathrm{C}$.

The primer pairs 27F, 5'-CGTATCGCCTCCCTCGCGCCATCAG-3' $5^{\prime}$-AGAGTTTGAT -CCTGGCTCAG-3'; 533R, 5' -CTATGCGCCTTGCCAGCCCGCTCAG-3'-MIDtags-5'-ATTA -CCGCGGCTGCTGGCA-3' were used to amplify V1-V3 regions of both the $16 \mathrm{~S}$ rDNA and $16 \mathrm{~S}$ rRNA transcripts (cDNA). The PCR program was run as follows: $95^{\circ} \mathrm{C}$ for $2 \mathrm{~min}$, followed by 25 cycles at $95^{\circ} \mathrm{C}$ for $30 \mathrm{~s}, 55^{\circ} \mathrm{C}$ for $30 \mathrm{~s}$, and $72^{\circ} \mathrm{C}$ for $30 \mathrm{~s}$, and a final extension at $72{ }^{\circ} \mathrm{C}$ for $5 \mathrm{~min}$. In addition, the reactions were performed in a $20-\mathrm{mL}$ mixture containing $4 \mu \mathrm{L}$ of $5 \times$ FastPfu Buffer, $2 \mu \mathrm{L}$ of $2.5 \mathrm{mM}$ dNTPs, $0.8 \mu \mathrm{L}$ of each primer $(5 \mu \mathrm{M}), 0.4 \mu \mathrm{L}$ of FastPfu Polymerase, and $10 \mathrm{ng}$ of template DNA or cDNA. Sterilized water was used to replace the template as a negative control to check for primer or sample contamination.

\subsection{4-Pyrosequencing and Sequence Analysis}

Purification was conducted using the AxyPrep DNA Gel Extraction Kit (Axygen Biosciences, Union City, CA, USA) and quantification was conducted using QuantiFluor ${ }^{\mathrm{TM}}$-ST (Promega, Madison, WI, USA), and then Roche 454 sequencing were performed using a mixture of amplicons (Roche 454 Life Sciences, USA) according to the Majorbio protocols (Shanghai, China). The raw reads were deposited into the NCBI SRA database (Accession Number: SRP081067).

Totally, 763,611 valid sequences and an average of 15,909 sequences per sample were found. QIIME (version 1.17) was used to process the resulting sequences. 630,009 highquality sequences were produced. Operational taxonomic units (OTUs) with $97 \%$ similarity cutoff were clustered using UPARSE software. In addition, the sequences were analyzed using the RDP Classifier against the SILVA (SSU 115) 16S rRNA database using a confidence threshold of $70 \%$ [36].

\section{5. $\alpha$-and $\beta$-Diversity Estimation, Taxonomy, and Statistical Analysis}

$\alpha$-diversity indices-Shannon and Simpson indices, Chao1, and ACE, based on $97 \%$ similarity OTUs calculated using Mothur $[37,38]$ were used to evaluate the bacterial structure. Principal coordinate analysis (PCoA) based on weighted UniFrac distance matrices was used to estimate the $\beta$-diversity which mainly indicate the bacterial community similarity [39].

The Dice similarity indexes were shown in a heat map with hierarchical clustering. These were used to analyze the differences among DNA- and RNA-based soil microbial communities at the OTU level under contrasting long-term fertilization regimes. SPSS 22 and Excel 2013 were used for statistical analysis.

The treatments effects on response variables, namely the relative abundance of bacterial phylum and class, using one-way ANOVA with the LSD test $(p<0.05)$. Redundancy discriminant analysis (RDA) was conducted to evaluate bacterial community effect of the relative contribution of manure- $\mathrm{C}$ (MA-C), rhizodeposition- $\mathrm{C}$, stubble- $\mathrm{C}$, and root- $\mathrm{C}$ - to total carbon input. Similarly, RDA evaluated the microbial community effect of $\mathrm{Cmin}$, $\mathrm{MBC}, \mathrm{DOC}, \mathrm{POC}, \mathrm{LFOC}$, and $\mathrm{KMnO}_{4}-\mathrm{C}$ - to TOC. Likewise, $\mathrm{RDA}$ evaluated the effect of soil chemical properties (TOC, TN, TP, Olsen- $\mathrm{P} \mathrm{NO}_{3}{ }^{-}-\mathrm{N}$, available $\mathrm{K}, \mathrm{C} / \mathrm{N}$, and $\mathrm{pH}$ ) on soil bacterial structures (phylum and class level) across the whole dataset with Canoco 5.0 (Ithaca, NY, USA).

\subsection{Network Analysis}

The complex interactions of bacterial communities under different treatments were determined by modeling them as a network [40,41]. The analysis was performed as Ling et al. [42]. The modular analysis was performed using the Gephi version 0.9.2. The line connecting two nodes (each node indicates an OTU—an individual taxon) delegates either a positive or a negative interaction. 


\subsection{Metagenome Inference}

PICRUSt (Phylogenetic Investigation of Communities by Reconstruction of Unobserved States) was used to predict the functional diversity of the DNA- and RNA-based bacterial taxa (http:/ / picrust.github.io/picrust). In addition, the 16S rDNA and 16S rRNA sequencing results were compared with the Greengenes database to select OTUs with high similarity to the "closed reference" database (the default is $\geq 97 \%$ ). The number of the corresponding sequences of each OTU was standardized by dividing by its $16 \mathrm{~S}$ copy number, based on the copy-number information in the corresponding OTU genome. Finally, the standardized data were multiplied by the corresponding gene content in the genome to achieve metagenomic prediction. The obtained prediction results can be classified into gene families by KEGG Orthology, COGs, or Pfams.

\section{Results}

3.1. Quantity and Diversity of Soil Bacterial Community under Long-Term Fertilization Regimes

After quality filtering, on average, there were approximately 9185 DNA reads per sample, and 9356 for RNA, resulting in 2869 and 2620 bacterial OTUs, respectively, at 97\% sequence similarity (Table 1). OTU richness, as measured by ACE and Chao1 indices, was higher for DNA samples than for RNA samples. However, species diversity (Shannon index and Simpson index) did not significantly or consistently differ between the two sets of samples. In DNA samples, differences between soil bacterial communities for different fertility treatments were demonstrated by the results of total OTUs, Chao1, and ACE (Table $1, p<0.05$ ). The highest number of OTUs and Chao1 were measured in the DF treatment, with the lowest number of OTUs, ACE, and Chao1 values observed in the DM treatment. Among the RNA samples, ACE was the only measure of $\alpha$-diversity affected by the treatment regime, with the highest and lowest values in FM and DM treatments, respectively.

Soil bacterial $\beta$-diversity responded strongly to the fertility treatments. When DNA and RNA results were pooled, hierarchical clustering (using Bray-Curtis dissimilarity) indicated clustering of DNA communities separately from RNA (Figure 1). DNA samples clustered together from treatments that received organic manure: the SM and FM treatments clustered as one group, then grouped with the DM treatment. DNA communities in SF were split evenly between clusters with CK and DF. Soil RNA-based communities in different fertility treatments showed similar clustering to the soil DNA communities except for those in DM treatments, suggesting that RNA communities in DM treatments were uniquely different from those in the other treatments. These differences were confirmed by the heatmap analysis of class-level affiliations using the most abundant 30 classes from each treatment, totaling 71 classes, from both DNA and RNA samples (Figure S1).

DNA and RNA-based bacterial communities showed markedly different when the 454 data were subjected to two-dimensional PCoA (Figure 2). The first two axes including axis1 and axis 2 accounted for $40.05 \%$ and $9.69 \%$ of the variation, respectively, and soil DNA-based communities were distinctly separated from the RNA-based communities along the first axis. The separation of the DNA communities was primarily along the second axis, with each fertility type resulting in a distinct bacterial community. For the RNA communities, the DM treatment was clearly separated from others along axis1, the SF treatment was separated from the FM and SM treatments along axis 2 (PCoA2). 

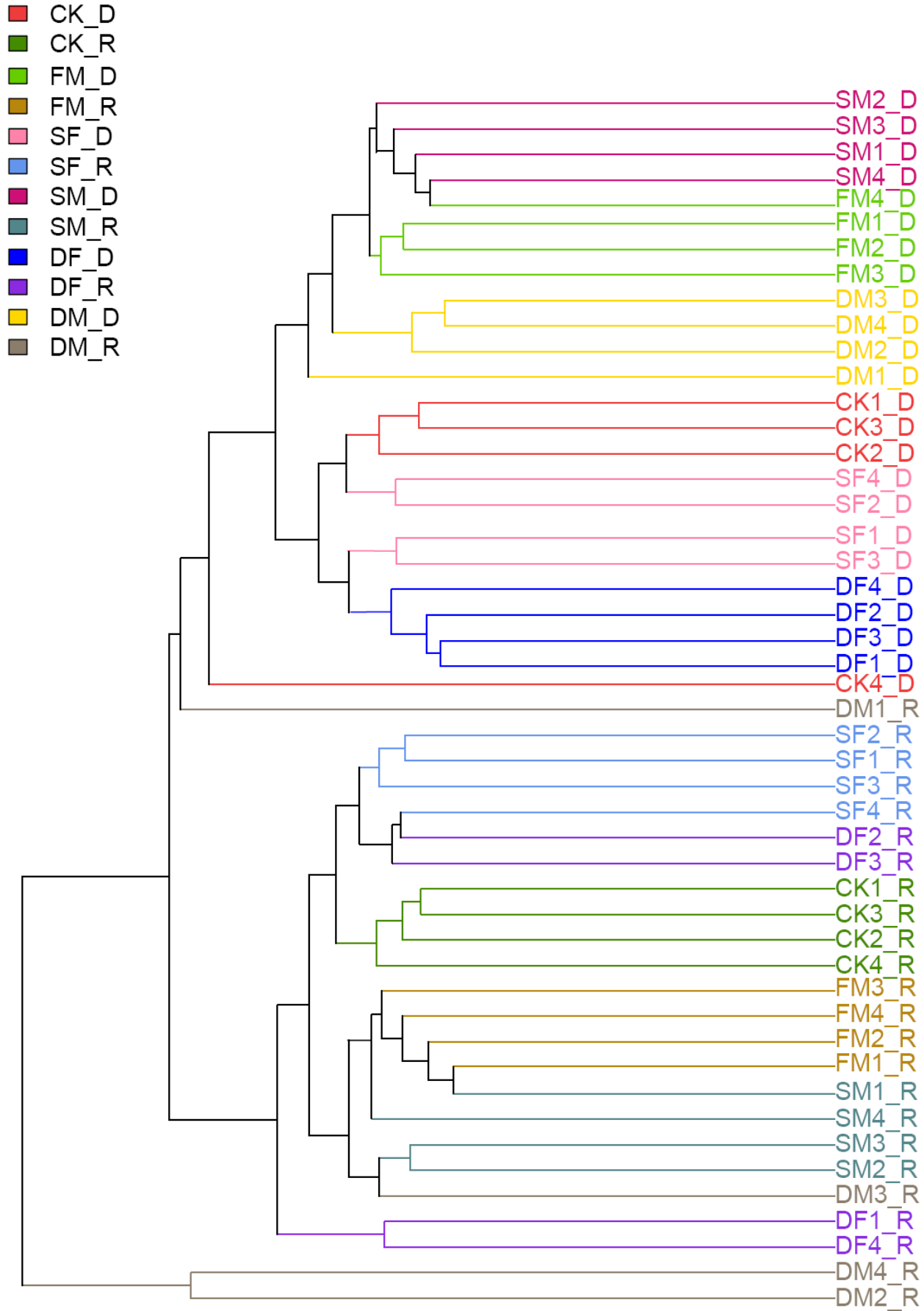

$\stackrel{\breve{0}}{0.1}$

Figure 1. Bray-Curtis similarity-based analysis for individual samples from all treatments. (CK: no fertilizer; SF: mineral fertilizer input; SM: cattle manure input; FM: half mineral fertilizer input plus half manure applied; DF: double amount mineral fertilizer input; DM: double amount cattle manure input. D indicates DNA-based, R indicates RNA-based). 

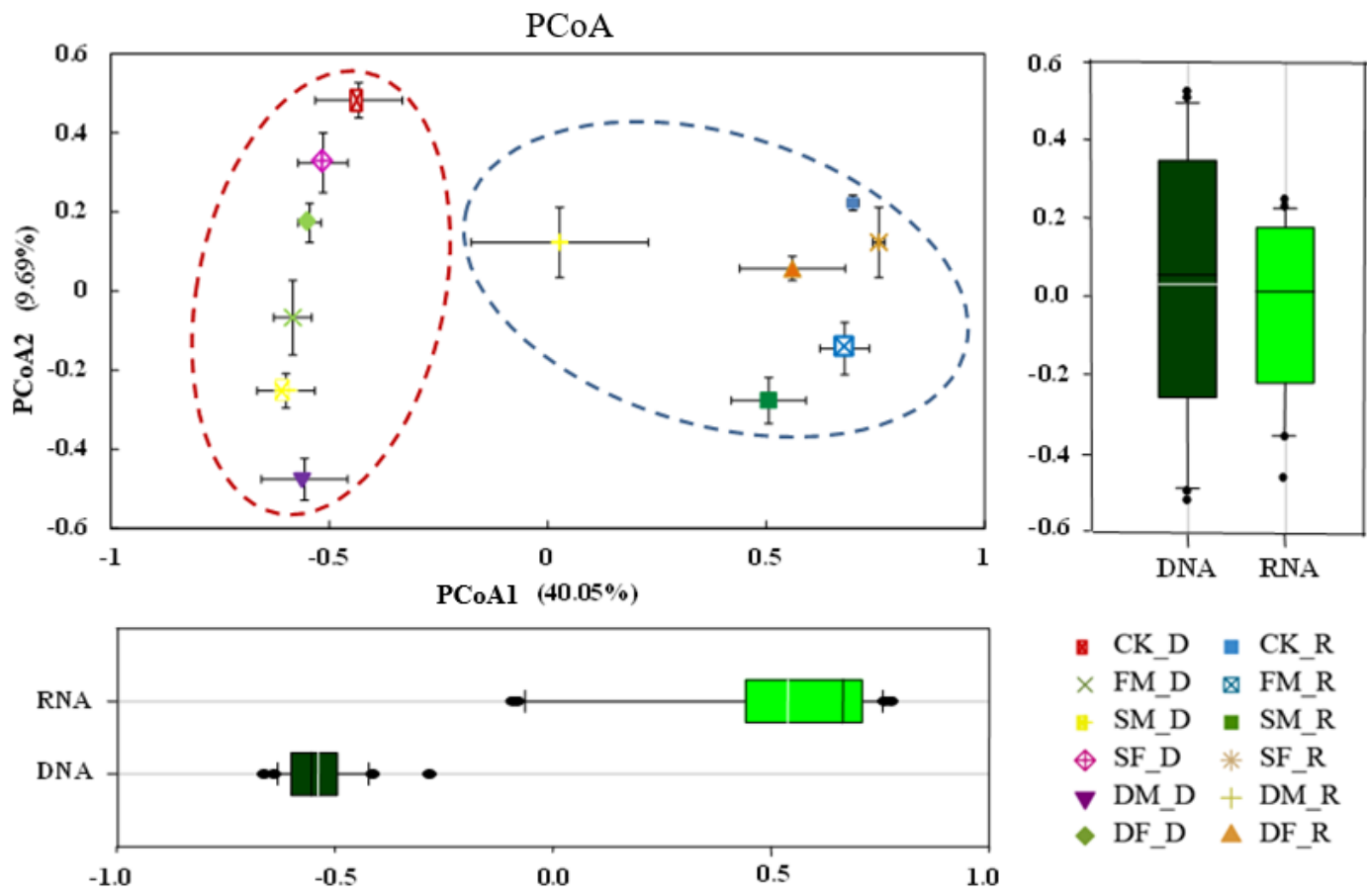

Figure 2. Principal coordinate analysis (PCoA) using 16S rDNA (DNA) and 16S rRNA (RNA) sequencing of long-term fertilized soil samples. (CK: no fertilizer; SF: mineral fertilizer input; SM: cattle manure input; FM: half mineral fertilizer input plus half manure applied; DF: double amount mineral fertilizer input; DM: double amount cattle manure input). The percent variation explained by each principal coordinate (PCo) is indicated on the axes.

Table 1. Changes in soil bacterial $\alpha$-diversity indices based on the data set of $16 \mathrm{~S}$ rDNA (DNA) and 16S rRNA (RNA) sequence assignments with a $97 \%$ sequence similarity (OTUs) in long-term fertilizer trial in the NCP revealed by 454 pyrosequencing. Different letter are significantly different (LSD, $p<0.05)$.

\begin{tabular}{ccccccc}
\hline & Treatments (T) & Total OTUs & ACE & Chao1 & Shannon & Simpson \\
\hline & CK-D & $2819 \pm 127 \mathrm{bc}$ & $4703 \pm 115 \mathrm{c}$ & $4547 \pm 50 \mathrm{~b}$ & $7.29 \pm 0.13 \mathrm{ab}$ & $0.0017 \pm 0.0006 \mathrm{ab}$ \\
& FM-D & $2998 \pm 192 \mathrm{ab}$ & $5663 \pm 661 \mathrm{a}$ & $4823 \pm 99 \mathrm{ab}$ & $7.37 \pm 0.13 \mathrm{a}$ & $0.0016 \pm 0.0007 \mathrm{ab}$ \\
DNA & SM-D & $2840 \pm 160 \mathrm{abc}$ & $4770 \pm 276 \mathrm{bc}$ & $4625 \pm 271 \mathrm{ab}$ & $7.30 \pm 0.04 \mathrm{ab}$ & $0.0015 \pm 0.0000 \mathrm{ab}$ \\
& SF-D & $3019 \pm 101 \mathrm{ab}$ & $4891 \pm 189 \mathrm{bc}$ & $4707 \pm 192 \mathrm{ab}$ & $7.38 \pm 0.06 \mathrm{a}$ & $0.0012 \pm 0.0002 \mathrm{~b}$ \\
& DM-D & $2485 \pm 199 \mathrm{c}$ & $4064 \pm 299 \mathrm{c}$ & $3874 \pm 316 \mathrm{c}$ & $7.08 \pm 0.12 \mathrm{~b}$ & $0.0021 \pm 0.0004 \mathrm{a}$ \\
& DF-D & $3052 \pm 172 \mathrm{a}$ & $5394 \pm 671 \mathrm{ab}$ & $4864 \pm 243 \mathrm{a}$ & $7.38 \pm 0.08 \mathrm{a}$ & $0.0013 \pm 0.0002 \mathrm{~b}$ \\
& T-D & $p<0.05$ & $p<0.05$ & $p<0.01$ & 0.1278 & 0.0819 \\
& CK-R & $2644 \pm 266 \mathrm{a}$ & $4145 \pm 399 \mathrm{bc}$ & $4046 \pm 417 \mathrm{ab}$ & $7.31 \pm 0.11 \mathrm{a}$ & $0.0012 \pm 0.0001 \mathrm{a}$ \\
& FM-R & $2735 \pm 299 \mathrm{a}$ & $4843 \pm 399 \mathrm{a}$ & $4235 \pm 339 \mathrm{a}$ & $7.30 \pm 0.12 \mathrm{a}$ & $0.0013 \pm 0.0004 \mathrm{a}$ \\
RNA & SM-R & $2586 \pm 226 \mathrm{a}$ & $4323 \pm 408 \mathrm{ab}$ & $4005 \pm 295 \mathrm{ab}$ & $7.23 \pm 0.11 \mathrm{ab}$ & $0.0014 \pm 0.0003 \mathrm{a}$ \\
& SF-R & $2659 \pm 217 \mathrm{a}$ & $4237 \pm 172 \mathrm{bc}$ & $4074 \pm 226 \mathrm{ab}$ & $7.28 \pm 0.09 \mathrm{ab}$ & $0.0014 \pm 0.0002 \mathrm{a}$ \\
& DM-R & $2468 \pm 156 \mathrm{a}$ & $3640 \pm 397 \mathrm{c}$ & $3546 \pm 342 \mathrm{~b}$ & $7.16 \pm 0.12 \mathrm{ab}$ & $0.0028 \pm 0.0005 \mathrm{a}$ \\
& DF-R & $2627 \pm 351 \mathrm{a}$ & $4415 \pm 415 \mathrm{ab}$ & $4022 \pm 298 \mathrm{ab}$ & $7.13 \pm 0.07 \mathrm{~b}$ & $0.0027 \pm 0.0007 \mathrm{a}$ \\
N (Nucleic & T-R & 0.8388 & $p<0.05$ & 0.3210 & 0.1990 & 0.0755 \\
Acid) & DNA average & $2869 \pm 211 \mathrm{a}$ & $4914 \pm 562 \mathrm{a}$ & $4573 \pm 363 \mathrm{a}$ & $7.30 \pm 0.12 \mathrm{a}$ & $0.0016 \pm 0.0003 \mathrm{a}$ \\
& RNA average & $2620 \pm 89 \mathrm{~b}$ & $4267 \pm 391 \mathrm{~b}$ & $3988 \pm 232 \mathrm{~b}$ & $7.24 \pm 0.08 \mathrm{a}$ & $0.0018 \pm 0.0007 \mathrm{a}$ \\
& N & $p<0.05$ & $p<0.05$ & $p<0.01$ & 0.2743 & 0.4948 \\
\hline
\end{tabular}

CK: no fertilizer; SF: mineral fertilizer input; SM: cattle manure input; FM: half mineral fertilizer input plus half manure applied; DF: double amount mineral fertilizer input; DM: double amount cattle manure input. Different letters within the same columns differ significantly $(p<0.05)$.

\subsection{Structure and Composition of Soil Bacterial Taxa}

Proteobacteria accounted for $29-45 \%$ of the bacterial sequences obtained from all samples and were the predominant phylum in both DNA-based and RNA-based communities (Figure 3a; Table S2). In the DNA-based community, Acidobacteria, Chloroflexi, Actinobacteria, and Planctomycetes followed Proteobacteria as the dominant phyla in all samples, followed 
by Bacteroidetes in OM-fertilized (SM, DM) soils and Gemmatimonadetes in the remaining treatments (CK, FM, SF, DF). In the metabolically active (RNA) community, the composition of the microbial communities was similar for standard rate fertilizer input treatments (FM, SF, and SM), the DF treatment, and CK. In addition, the top five phyla were Proteobacteria, Acidobacteria, Actinobacteria, Planctomycetes, and Chloroflexi, followed by Nitrospirae. Firmicutes and Bacteroidetes distinctly displayed a higher abundance in DM than others. In only the CK communities was there evidence that Nitrospirae had a higher transcriptionally active population than Chloroflexi. These results showed that the distinct influences of fertilization on the composition of soil bacteria can be revealed in the DNA or RNA datasets at the phylum level. For instance, while Nitrospirae were highly enriched in the CK treatment (in both the DNA and RNA datasets), the RNA-based data indicated that Actinobacteria, Firmicutes, and Bacteroidetes were highly enriched in the double-rate OM input (DM-R), while the abundances of Proteobacteria, Acidobacteria, and Nitrospirae were lower.

Deeper taxonomic profiling showed that 31 bacterial classes with abundances $>1 \%$ were found across all samples (Figure 3b, Table S3). The dominant classes in DNA-based communities across all treatments were Acidobacteriia (12.0-15.6\%), Deltaproteobacteria (7.2-8.4\%), Alphaproteobacteria (8.3-9.9\%), Betaproteobacteria (6.9-10.0\%), and Gammaproteobacteria (5.3-7.4\%). These two phyla (Acidobacteria and Proteobacteria) accounted for up to $51.3 \%$ of all the sequences. Deltaproteobacteria, Alphaproteobacteria, and Acidobacteriia were revealed to be the top three classes in the RNA-based communities among all treatmentsexcept the DM treatment, which had Alphaproteobacteria, Actinobacteria, and Bacilli as the top three classes. The comparation of DNA and RNA sequencing analysis showed that RNA-based communities had significantly higher abundances of Deltaproteobacteria, Alphaproteobacteria, and Actinobacteria classes, and significantly reduced proportions of Betaproteobacteria, Gammaproteobacteria, Anaerolineae, and Cytophagia.

In the DNA analysis, fertility treatment significantly affected the relative abundance of the bacterial classes (Figure 3b, Table S3) $(p<0.05)$. Betaproteobacteria and Gammaproteobacteria were significantly more abundant in organic manure-treated soils (FM, SM, and DM), while mineral fertilizer-treated soils had higher abundances of Gemmatimonadetes. The relative abundance of Nitrospira was slightly higher in CK soils, followed by the mineral-fertilized soils (SF and DF), then the organic manure-fertilized soils (FM, SM, and DM).

The abundance of RNA-based bacteria at class level showed clearly different among the six treatments $(p<0.05)$, especially in DM treatment $(p<0.05)$. For instance, the Deltaproteobacteria (15-26\%) class was the most abundant (peaking at $26.37 \%$ relative abundance in the CK) in all treatments except for DM, which had the lowest Deltaproteobacteria abundance at $6.5 \%$. The dominant class in DM soils was Alphaproteobacteria with $13 \%$ relative abundance; DM soils also had higher abundances of Actinobacteria (11.6\%), Bacilli (9.1\%), Clostridia (7.6\%), and Bacteroidia (4.8\%) compared with the other treatments. In addition, the relative abundance of Bacilli in the DM treatment was investigated to be 8.3 times of that in the CK treatment, and 6.6 times of that in the DF treatment. Furthermore, Acidobacteriia, Planctomycetacia, Holophagae, Nitrospira, and Cyanobacteria were significantly less abundant following DM treatments compared with other treatments. Nitrospira was found to have the highest abundance in the CK treatment, while Cyanobacteria and Anaerolineae showed the highest abundance in soils amended with mineral fertilizer alone (DF, SF). Moreover, Gammaproteobacteria had significantly higher abundances in organic manure-treated soils (FM, SM, and DM) $(p<0.05)$, followed by mineral-fertilized soils (SF, DF), and the CK treatment. 
(a)

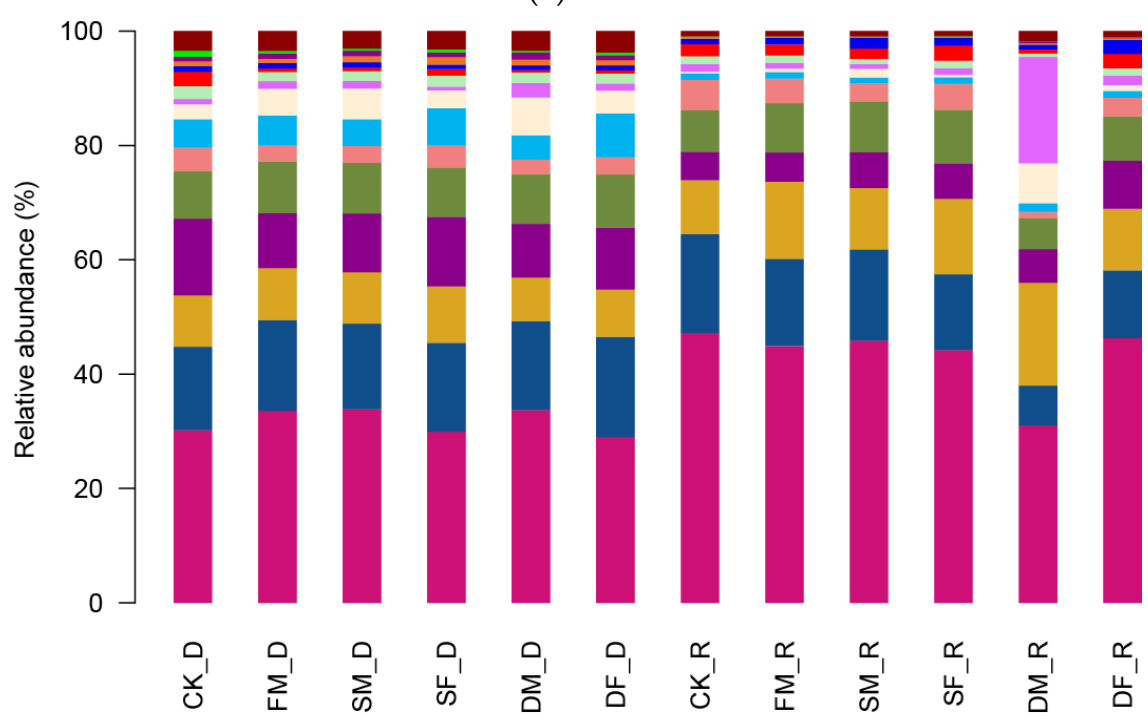

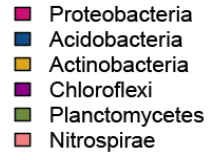

$\square$ Nitrospirae

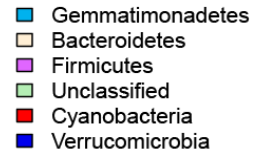

$\square$ Gemmatimonadetes

$\square$ Bacteroidetes

$\square$ Firmicutes

$\square$ Cyanobacteria

- Verrucomicrobia

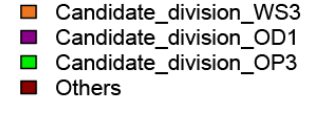

Gandidate division OD1

$\square$ Candidate_division_OP3

(b)
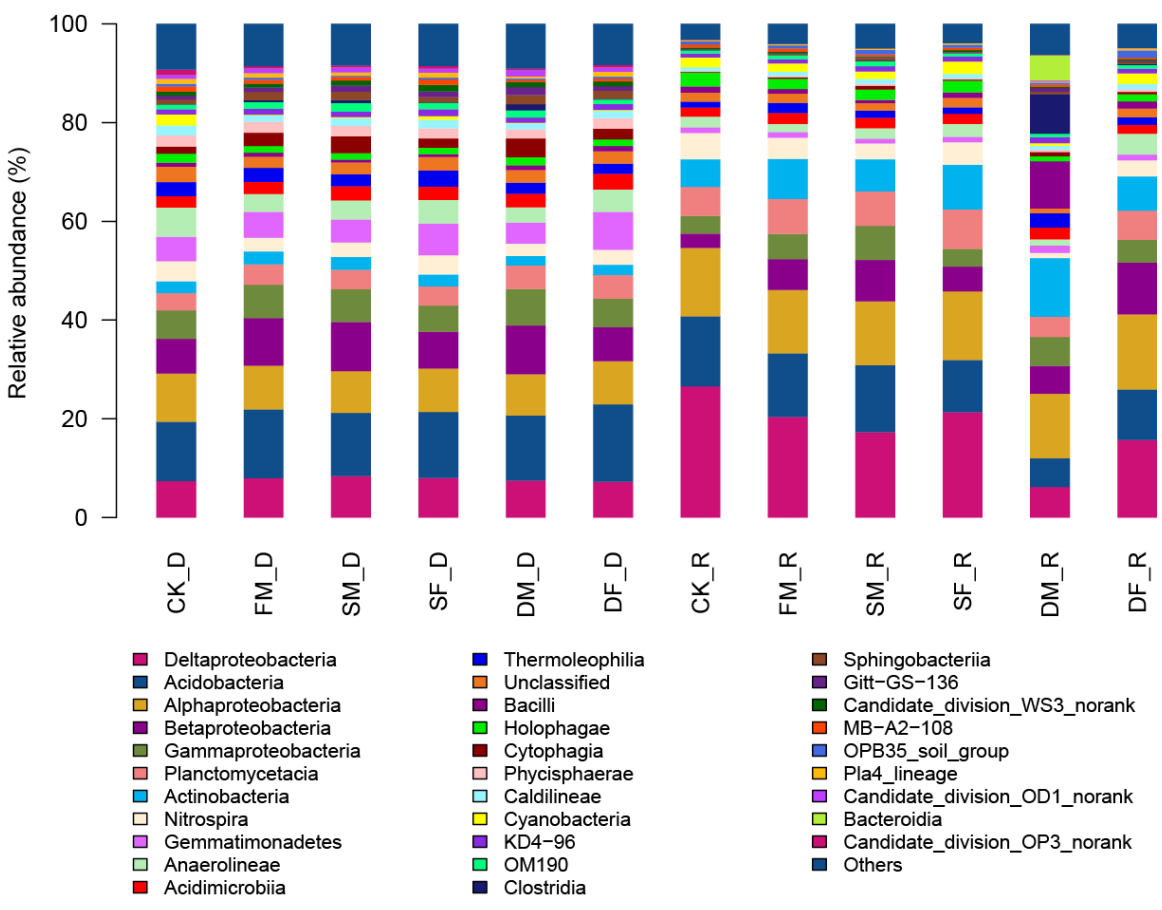

Figure 3. Changes in the abundances of bacterial phylum (a) and class (b) based on 16S rDNA and 16S rRNA sequencing under long-term fertilization regimes (D indicates DNA-based, $R$ indicates RNA-based).

\subsection{Network Analysis between DNA and RNA Levels}

Markedly different structures for the DNA- and RNA-based bacteria were showed in Figure 4a,b. DNA-based soil network contained 67 nodes and 609 edges $(57.81 \%$ positive correlation); there were three modules in the network, bacterial OTUs in the same module had closer relationships, and Flavobacteria represented the greatest connection with others. For the RNA-based soil samples, the network contained 57 nodes and 643 edges $(73.41 \%$ 
positive correlation); there were also three modules in the network, and Planctomycetacia represented the maximum connection with others (Table 2).

(a)

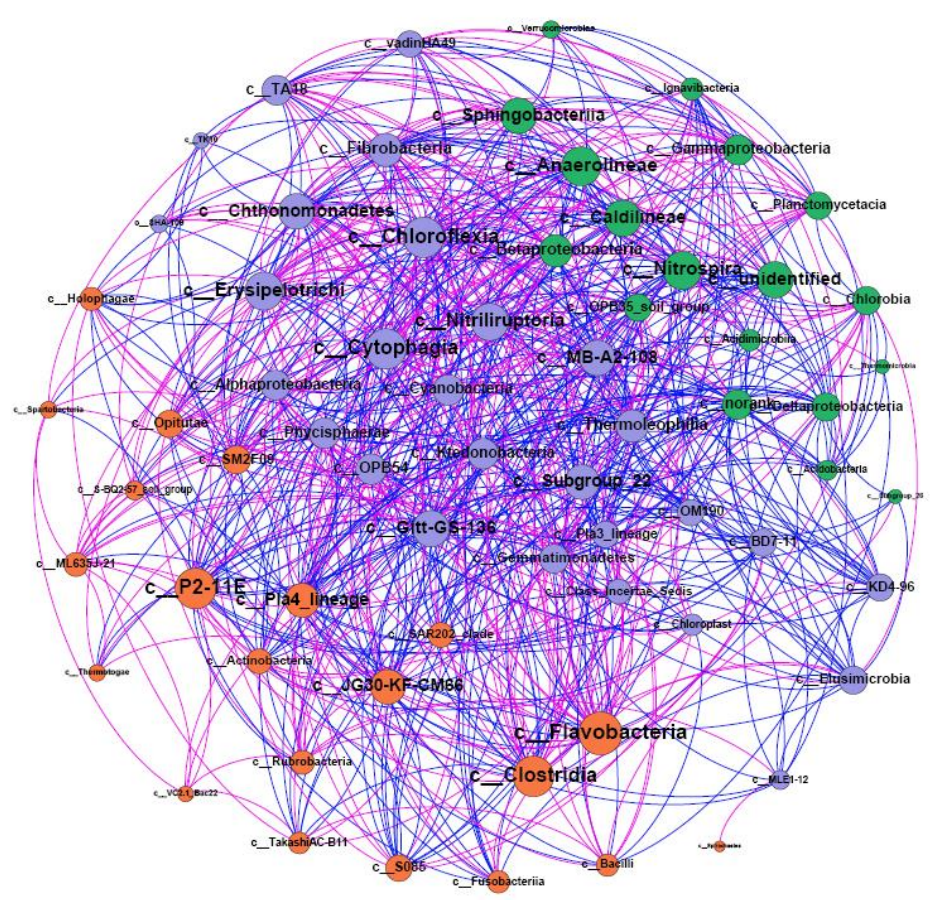

(b)

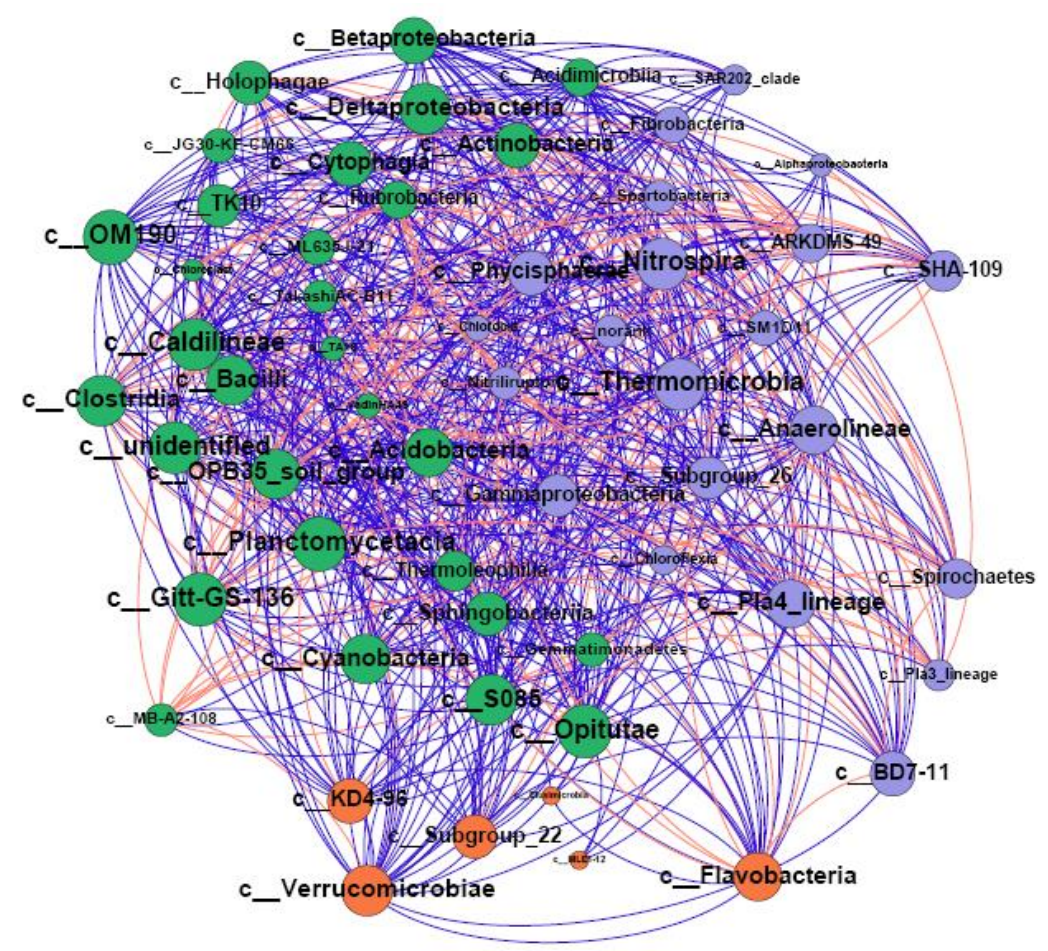

Figure 4. Network analysis of (a) DNA-based bacterial community data set; and (b) RNA-based bacterial community data set at class level under long-term fertilization regimes. Each node represents an individual OTU. $\cdots$ represent different modules and the nodes in the same color indicate positive correlations with each other. Red lines represent positive and blue lines represent negative correlations between the two OTUs. 
Table 2. Network analysis of DNA- and RNA-based soil bacterial communities at class level in the long-term fertilizer trial.

\begin{tabular}{ccc}
\hline Network Metrics & \multicolumn{2}{c}{ Groups } \\
\cline { 2 - 3 } & DNA & RNA \\
\hline Number of nodes & 67 & 57 \\
Total number of edges & 730 & 643 \\
Number of positive correlations & 0.58 & 0.73 \\
Number of negative correlations & 0.42 & 0.27 \\
Average path length & 1.719 & 1.616 \\
Average clustering coefficient & 0.517 & 0.567 \\
Average degree & 21.791 & 22.561 \\
Connect components & 1 & 1 \\
\hline
\end{tabular}

\subsection{Functional Analysis between DNA and RNA Levels}

PICRUST detected total 41 level 2 KEGG Orthology groups (KOs). In addition, KEGG pathways having significant differences between DNA and RNA-based bacteria in each treatment were explored, resulting in a significant variation (Figure S2). Eight KEGG pathways (genetic information processing; glycan biosynthesis and metabolism; nucleotide metabolism; transcription; translation; replication and repair; folding, sorting and degradation; and signal transduction) were markedly enriched in most DNA-based bacterial communities $(p<0.05)$, and 11 KEGG pathways (metabolism; sensory system; xenobiotics biodegradation and metabolism; metabolism of other amino acids; metabolism of terpenoids and polyketides; immune system diseases; cardiovascular diseases; cancers; membrane transport; signaling molecules and interaction; transport and catabolism) were markedly enriched in most RNA-based communities $(p<0.05)$.

\subsection{Taxonomic Composition of Bacterial Communities Compared against Environmental Conditions Affected by Fertilization Regimes}

RDA revealed the effects of soil chemical properties (Figure $5 a, b)$; the contribution of carbon inputs to TOC (Figure $6 a, b$ ); and the ratio of labile SOC fractions to TOC as drivers of DNA and RNA-derived phyla of soil bacteria (Figure 7a,b). Figure 5a illustrates how soil chemical properties drive different DNA-based bacterial structure. The first two axes explain $34.31 \%$ and $13.17 \%$ ( $47.48 \%$ in total) of the variation, respectively. TOC $(p<0.001)$, TN $(p<0.001)$, Olsen-P $(p<0.001), \mathrm{NO}_{3}{ }^{-}-\mathrm{N}(p<0.01)$, available $\mathrm{K}$ $(p<0.01)$ are all significantly positively correlated along axis RDA1; C/N $(p<0.05)$ and $\mathrm{pH}(p<0.001)$, however, show negative relationships along axis RDA1. TOC, TN, and $\mathrm{pH}$ were the best predictors of the relative abundance of soil DNA-based bacterial phyla in the forward selection method. Increases in $\mathrm{pH}$ were correlated with Cyanobacteria and unclassified organisms, while $\mathrm{C} / \mathrm{N}$ ratio was correlated with increased relative abundances of Nitrospirae and Chloroflexi, and to a lesser extent, Actinobacteria. There was a strong correlation between Bacteroidetes and indicators of soil fertility (TOC, Olsen-P, TN, and available $\mathrm{K})$, which clearly separated the DM community from the other treatment communities along RDA1. The presence of Acidobacteria was negatively correlated with soil $\mathrm{pH}$ and separated the double fertilizer (DF) treatment community from other communities in the lower left quadrant of Figure 5a.

Differences between soil chemical properties as drivers of the metabolically active (RNA-based) communities were similar to the observations in the DNA-based communities: $\mathrm{NO}_{3}{ }^{-}-\mathrm{N}(p<0.001)$, available $\mathrm{K}(p<0.001)$, TOC $(p<0.01)$, TN $(p<0.01)$, Olsen-P $(p<0.01), \mathrm{C} / \mathrm{N}(p<0.01)$, and $\mathrm{pH}(p<0.05)$ were all significant drivers of community structure along RDA1. The best predictors were TOC, $\mathrm{NO}_{3}{ }^{-}-\mathrm{N}$, and Olsen-P, as revealed by the stepwise forward selection procedure. The RNA-based bacteria in DM treatment showed significantly different from those in other treatments and correlated with the indicators of soil fertility, including Olsen-P, TN, and available K (Figure 5b). 
(a)

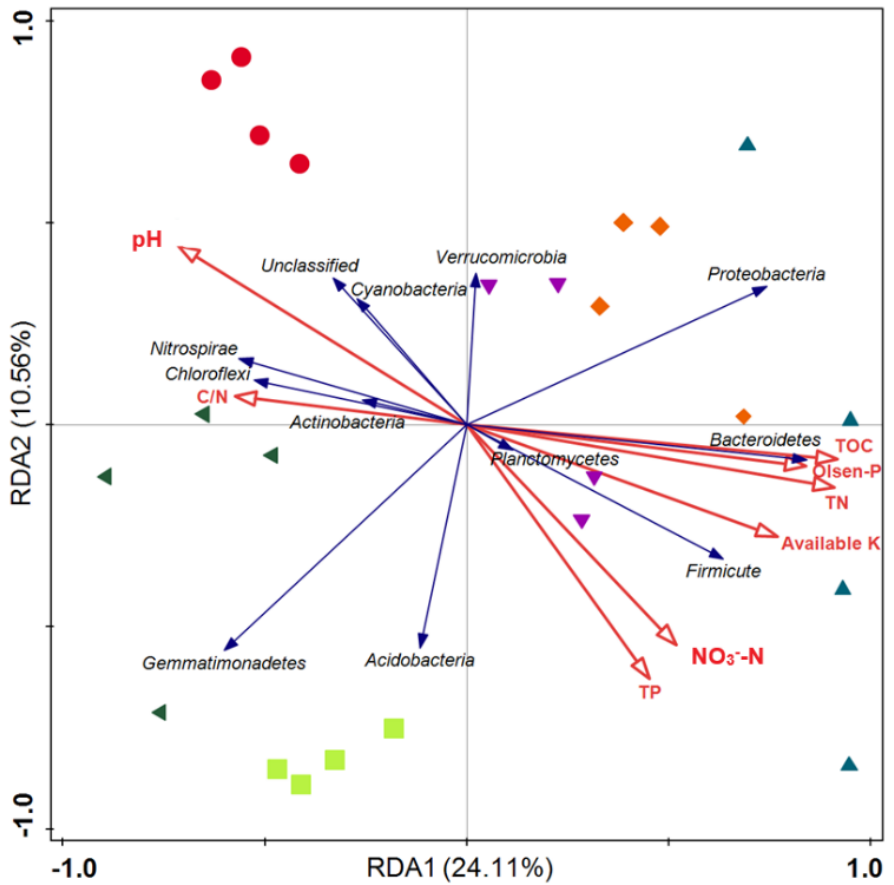

(b)

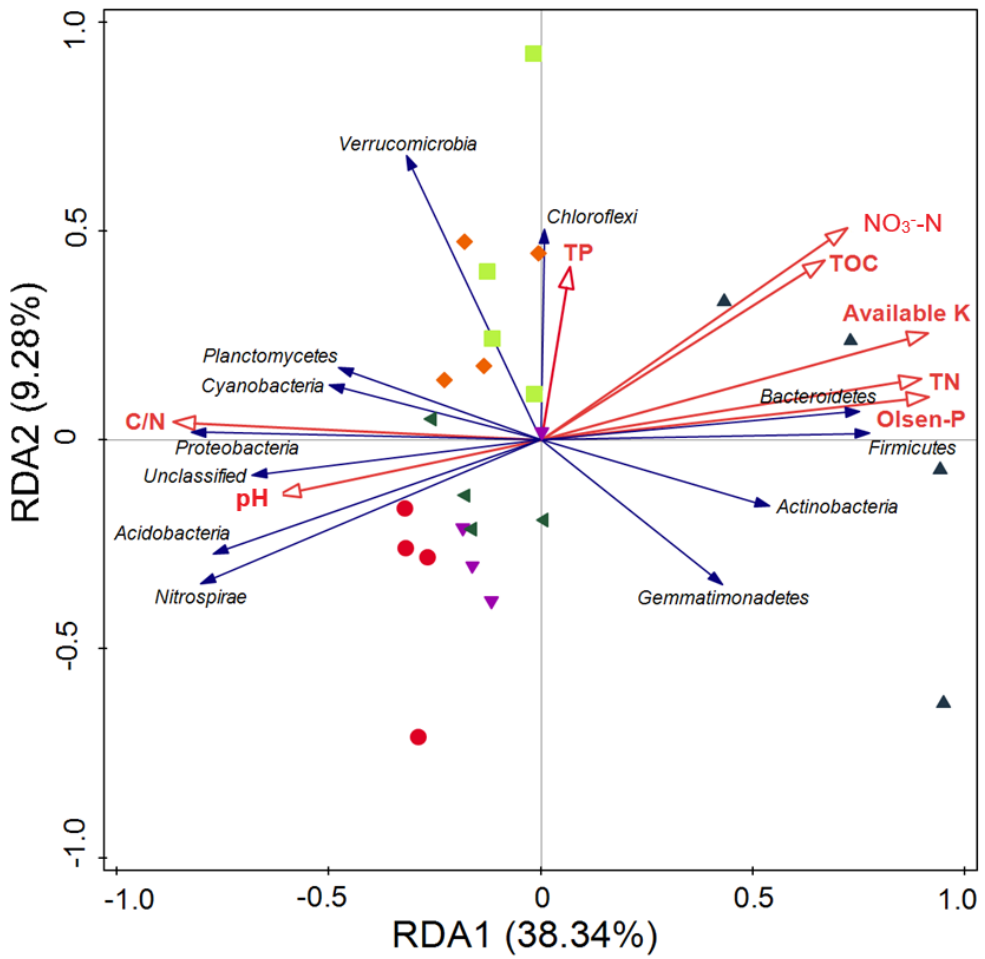

Figure 5. RDA of the effects of environmental variables (TOC, TN, TP, Olsen- $\mathrm{P} \mathrm{NO}_{3}{ }^{-}-\mathrm{N}$, Available $\mathrm{K}, \mathrm{C} / \mathrm{N}$, and $\mathrm{pH}$ ) on the DNA- (a) and RNA-based (b) bacterial phylum from different long-term fertility treatments. ( $\bullet$ CK: no fertilizer; $\measuredangle$ SF: mineral fertilizer input; $\diamond$ SM: cattle manure input; $\nabla$ FM: half mineral fertilizer input plus half manure applied; DF: double amount mineral fertilizer input; $\Delta$ DM: double amount cattle manure input). 
(a)

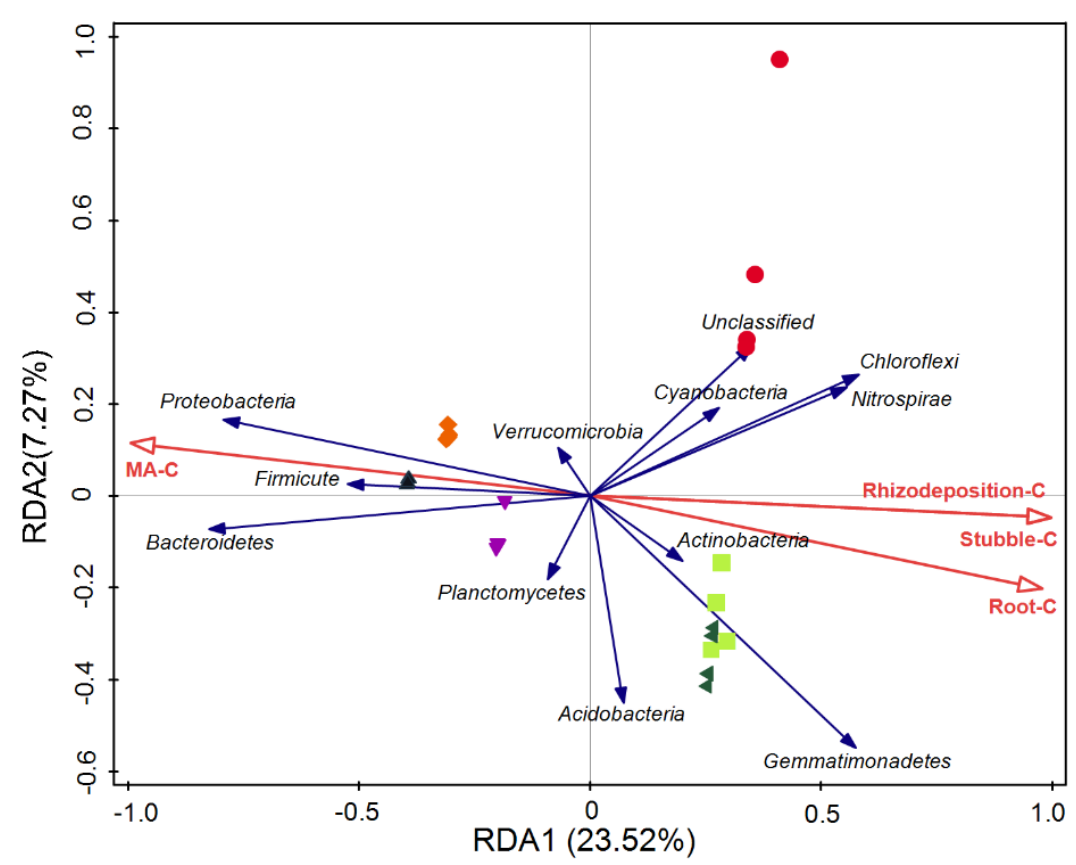

(b)

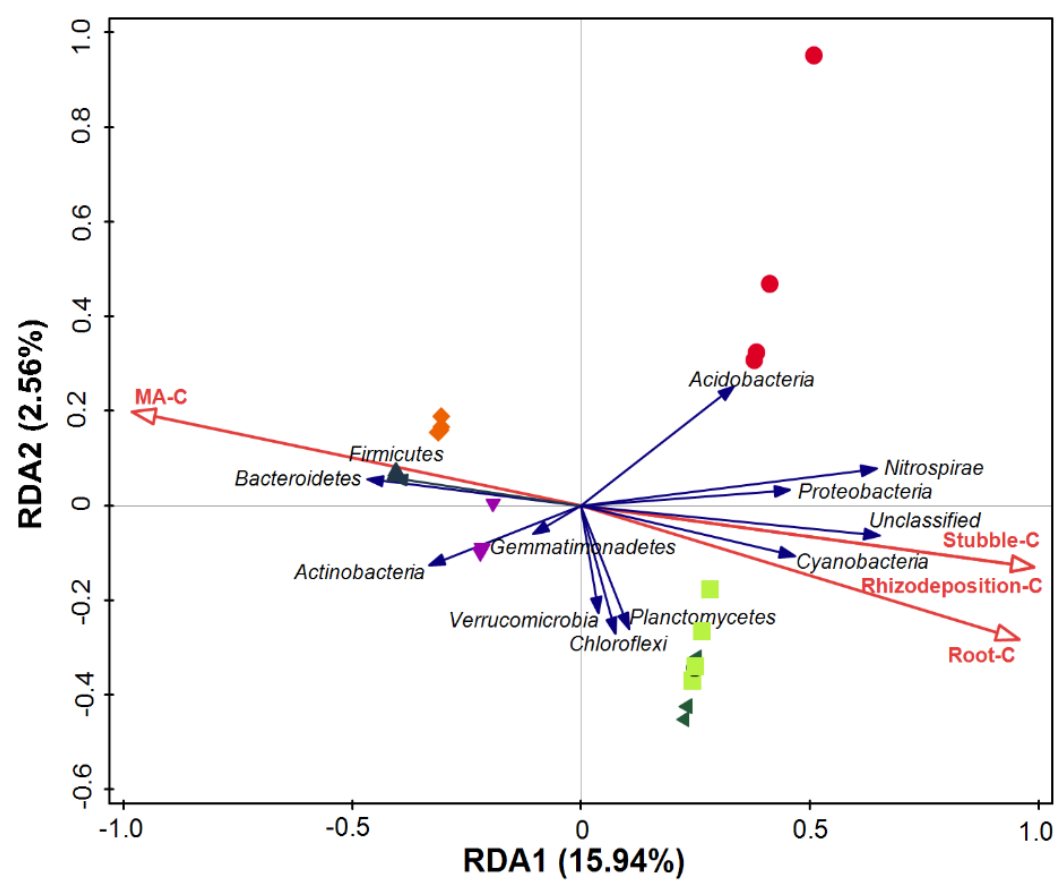

Figure 6. RDA of soil DNA-based (a) and RNA-based (b) bacterial communities at the phylum level constrained by the proportion of each C input to total C input. ( $\bullet$ CK: no fertilizer; $\langle$ SF: mineral fertilizer input; $\diamond \mathrm{SM}$ : cattle manure input; $\mathbf{\nabla}$ FM: half mineral fertilizer input plus half manure applied; $\square$ DF: double amount mineral fertilizer input; $\boldsymbol{\Delta}$ DM: double amount cattle manure input). 
(a)

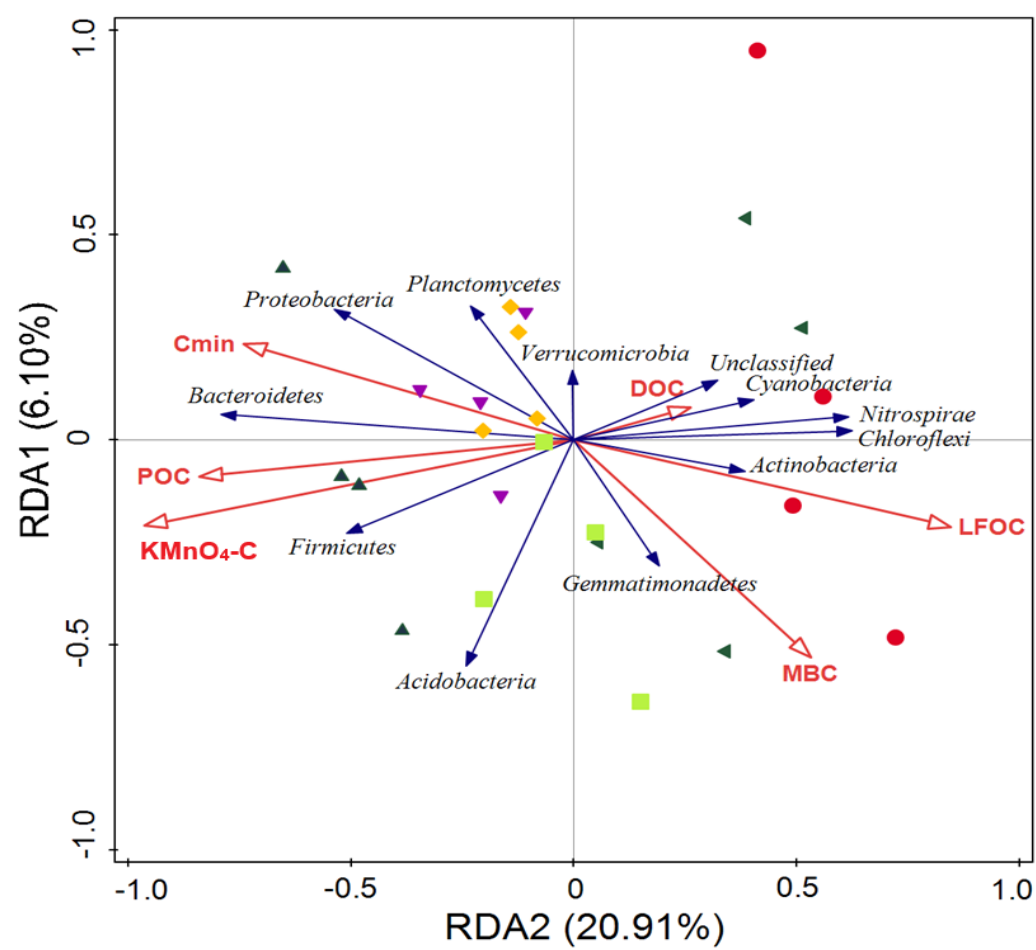

(b)

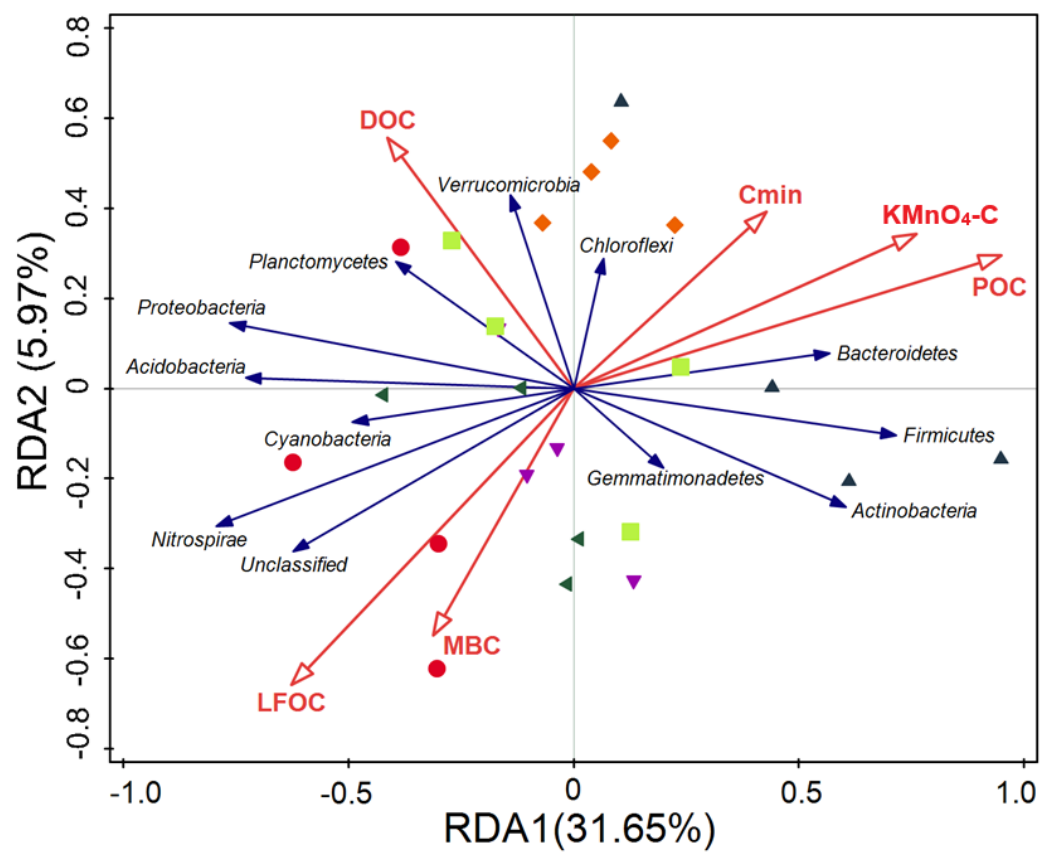

Figure 7. RDA of soil DNA-based (a) and RNA-based (b) bacterial communities at phylum level constrained by the proportion of each labile OC fraction to TOC in the long-term fertilizer trial. (• CK: no fertilizer; $\$ SF: mineral fertilizer input; $\diamond$ SM: cattle manure input; $\nabla$ FM: half mineral fertilizer input plus half manure applied; DF: double amount mineral fertilizer input; \ DM: double amount cattle manure input).

Investigating the impacts of carbon inputs on bacterial community structure revealed that MA-C was highly correlated with DNA-based Proteobacteria, Firmicutes, and Bacteroidetes (Figure 6a). Treatments dominated by stubble- $\mathrm{C}$, rhizodeposition- $\mathrm{C}$, and root- $\mathrm{C}$ (CK, SF, and DF) were somewhat correlated with populations of Chloroflexi, Nitrospirae, and 
Gemmatimonadetes. In the RNA communities, Firmicutes and Bacteroidetes again showed positive relationships with MA-C $(p<0.05)$, and Cyanobacteria, Proteobacteria, unclassified organisms, and Nitrospirae were highly correlated with stubble-C, rhizodeposition-C, and root-C $(p<0.05)$. Forward selection showed that MA-C was the primary driver of soil in both the DNA- and RNA-based communities (Figure 6b).

Soil organic carbon fractions contributed to the soil bacterial community structure, with $\mathrm{POC}$ and $\mathrm{KMnO}_{4}-\mathrm{C}$ strongly associated with DNA-based Proteobacteria, Planctomycetes, Verrucomicrobia, Firmicutes, and Bacteroidetes, while DNA-based Actinobacteria and Chloroflexi were positively correlated with LFOC. RNA-based Proteobacteria showed a strong association with LFOC. For both DNA and RNA communities, Firmicutes and Bacteroidetes showed positive relationships with $\mathrm{POC}$ and $\mathrm{KMnO}_{4}-\mathrm{C}$; however, Acidobacteria, Cyanobacteria, and Nitrospirae showed a higher correlation with LFOC. Forward selection showed that $\mathrm{KMnO}_{4}-\mathrm{C}$ and POC were the primary $\mathrm{C}$ fractions causing differences in the DNA- and RNA-based bacteria, respectively (Figure 7a,b).

\section{Discussion}

\subsection{Dominant Phyla Reflect Those Commonly Found in Agricultural Soils}

The soil bacterial communities of the present study reflected those commonly reported in other studies on agricultural soils [43]. Zhao [44] also reported similar dominant phyla across soil samples in wheat-summer cropping systems, including Proteobacteria, Acidobacteria, Chloroflexi, Bacteroidetes, Verrucomicrobia, Actinobacteria, Gemmatimonadetes, Firmicutes, and Planctomycetes (relative abundance $>1 \%$ ). The dominance of Proteobacteria $(48.6 \%$ ) and Acidobacteria (15.3\%) we identified in both the RNA-based and DNA-based bacterial communities was consistent with the observations in previous studies [44-47] (Figure 3a). These two phyla, along with Actinobacteria, have reportedly been the dominant groups in studies of other environments-including the Arctic [48], coniferous forests [49], and 237 locations across six continents globally [50]-confirming the common pattern of the dominant phyla within soil bacterial communities, although the relative abundances may vary $[45,46,51,52]$.

\subsection{RNA-Based Bacteria Have Lesser Species Diversity and Evenness but Greater Functional Connections Compared with DNA-Based Bacteria}

Within a given treatment, the relative abundances of phyla differed between the RNA and DNA communities, suggesting differential relative transcriptional activities per bacterial taxon (Figure 3a, Table S1). RNA-based communities exhibited lower $\alpha$-diversity values than those of DNA-based communities (Table 1), indicating that not all bacterial species present were metabolically active at the time of sampling. Liang [53] and Gill [54] indicated that the relative abundances of RNA-based taxa were not predicted by their abundances in DNA-based communities under different environmental conditions. Furthermore, RNAbased taxa possessed higher positive connections with other taxa, suggesting that more positive interactions provide a deeper degree of cooperation in soil bacteria [55]. This highlights the limitations of DNA-based surveys, which do not distinguish between active (RNA-based) and dormant portions of microbial populations [56].

The actively metabolizing soil bacterial community at any given time will be affected by series often transient environmental factors. Our samples were collected in October, immediately following the maize harvest. At the time of sample collection, the average daily temperatures ranged from $9{ }^{\circ} \mathrm{C}$ to $21{ }^{\circ} \mathrm{C}$ over a 24 -h period. Soil water content was approximately $20 \%$; in the week prior to sampling there had been no precipitation. These conditions contrasted with the summer and winter temperatures at the site, which average a maximum of $32{ }^{\circ} \mathrm{C}$ and a minimum of $-7{ }^{\circ} \mathrm{C}$, respectively. Orr [10] indicated considerable variation in the abundance of metabolically active bacteria in a fertility input trial over three years, and seasonally within a given year, with no clear pattern. In the present study, it is likely that conditions during the sampling period favored the activity of bacteria adapted to cool and dry conditions. 
The relative abundance of metabolically active (RNA-based) phyla may be driven not only by temperature and moisture, but also by substrate availability. As our samples were taken after the maize harvest, the quantities of root exudates in the soil would have been much lower than during the growing season; this may have favored the activity of heterotrophs adapted to access $C$ from more recalcitrant pools of native soil C. PICRUSt analysis revealed that in the DNA samples, the predicted genes involved in glycan biosynthesis and metabolic pathways contributing to the degradation of glycan in cellulose and hemicellulose were markedly increased (Figure S2), which is in consistent with the report showing that Acidobacteria were more abundant in DNA samples and were closely associated with LFOC [57]. The RNA samples were positively related to the metabolism of amines/amides, xenobiotics, lipids, terpenoids, and polyketides (Figure S2), which are all important components of POC. It has also been previously reported that Bacillus has a high degradation capacity for amino acids, carbohydrates, and carboxylic acids [58], which our study has demonstrated to have a positive relationship with POC. Larger differences between DNA and RNA analyses of soil bacterial communities indicate that some active bacterial communities respond differently to various external conditions, and that these differences can manifest over shorter and longer time scales [59,60].

\subsection{Significant Effects of Long-Term Fertilization on Bacterial Communities}

The relative abundances of DNA- and RNA-based bacterial phyla in our study were clearly driven by differences in soil chemical properties. Abundances of Bacteroidetes and Firmicutes, in both DNA and RNA, were closely related to soil properties indicative of fertility - for example Olsen-P and total N (Figure 5a,b) —reflecting the copiotrophic (fastgrowing r-strategists that prefer $\mathrm{C}$-rich conditions) nature of these phyla. For the metabolically active (RNA-based) component of the bacterial population (Figure 5b), available K was also an important driver of relative abundance, while for the total population (Figure 5a) TOC played a key role. Phyla representative of slower-growing oligotrophic bacteriafor example Acidobacteria, Planctomycetes, Verrucomicrobia, Nitrospirae, and Cyanobacteria (Figure 3a, Table S2) — were less abundant in manure-amended treatments and showed significantly positive correlations with soil $\mathrm{pH}$ but negative relationships with TN and TOC (Figure 5). Acidobacteria, with 26 subgroups [61], are ubiquitous and abundant soil bacteria [62]. Some have shown negative correlations with soil $\mathrm{pH}$ [62], while others are favored in acidic soils [63], which are supported by the studies that have reported a lower proliferation of Acidobacteria when exposed to organic amendments in sediments [64], under organic farming practices [15], and in all plots treated with fertilizers, compared to the control [65]. This is consistent with their ecological niche as slow-growing oligotrophs or Kstrategists-microorganisms that compete and survive in resource-poor conditions $[62,66]$. When $C$ availability is high, Acidobacteria cannot compete with fast-growing denitrifiers under high $\mathrm{N}$ availability [67].

Since TOC is a key driver, our results suggest that the accumulation of soil $\mathrm{C}$ from the long-term application of manure results in bacterial populations dominated by the Bacteroidetes. This was supported by the slightly lower indices of $\alpha$-diversity for the DM treatment in our study, indicating the preferential growth of phyla adapted to high fertility and high inputs of organic C. However, in other cases, OM or combined OM and mineral fertilizer input increased soil bacterial diversity in several long-term experiments in China $[15,68]$. Responses of specific microbial groups to mineral fertilizers or manure inputs over the long term $[69,70]$ varies and seems to depend on the initial soil conditions, the duration of treatment, fertilizer input rates, and other crop management-related factors [71,72].

RDA analysis using results from a previously published C-fraction study [33] indicated that Bacteroidetes, in particular, are adapted to conditions where particulate organic C (POC) is proportionally a dominant form of C. Nearly $25 \%$ of the total C in the DM treatment was POC in that study, while the other treatments had less than 20\% POC [33]. POC is a relatively accessible form of $\mathrm{C}$, along with $\mathrm{KMnO}_{4}-\mathrm{C}$ and mineralizable $\mathrm{C}(\mathrm{Cmin})$, 
which is reflective of decomposing residues that rapidly turn over [33]. Bacteroidetes is a copiotrophic taxon that, along with Proteobacteria, Actinobacteria, and Firmicutes, dominates in nutrient-rich environments. Both Bacteroidetes and Firmicutes were highly correlated with soil fertility indicators for both DNA- and RNA-based bacteria; however, the C/N ratio, indicative of soils that contain resistant pools of $\mathrm{C}$ and low nutrient availability $[67,73]$, affected the active (RNA-based) Proteobacteria significantly. These findings support the view that OM input over 27 years promotes specific bacterial populations as compared to mineral fertilizer application in a fluvo-aquic soil (Figure 2), resulting in communities developing that fill different ecological niches (e.g., soil $\mathrm{pH}$, carbon, nitrogen, $\mathrm{NO}_{3}{ }^{-}-\mathrm{N}$, Olsen-P), and that certain active (RNA-based) bacterial taxa can display properties of ecological coherence [63].

Soil $\mathrm{pH}$ was reported to be the strongest factor determining bacterial community composition [74,75], not only for microbial functional genes but also for mRNA transcript abundance [76]. Lauber et al. [77] found higher incidences of Proteobacteria in lower $\mathrm{pH}$ soils in a long-term fertility input trial on acid black soils under N-P-K input compared to OM input [78,79]. Responses of the RNA-based population of Proteobacteria differed from the DNA-derived one due to the negative relationship between the RNA-based population and soil pH or OM input amount (Figure 3a, Figure 5b). Deeper mining of soil bacterial taxa at the class level helped to explain this difference. The Proteobacteria classes that differed between DNA- and RNA-based bacteria in CK and mineral-fertilized treatments (SF, DF) were Alphaproteobacteria and Deltaproteobacteria, whereas the FM, SM, and DM treatments had higher relative abundances of Betaproteobacteria and Gammaproteobacteria (Figure 3b, Table S3). For DNA-based Proteobacteria, the dominant classes-Betaproteobacteria and Gammaproteobacteria - showed a negative relationship with soil $\mathrm{pH}$ and a positive relationship with Bacteroidetes and Actinobacteria, which are recognized as copiotrophic (Figure S3). Deltaproteobacteria are a key functional component of anaerobic microbiology and are related to dissimilatory sulfur and sulfate reduction. The highest abundance of active (RNA-based) Deltaproteobacteria was found in CK, suggesting that the input of fertilizers actively suppresses dissimilatory sulfur and sulfate reduction cycling [63,80].

Actinobacteria are of great importance to the $\mathrm{C}, \mathrm{N}$ cycles of global biological systems [81]. In our study, Actinobacteria were proportionally more dominant in the RNA than in the DNA fractions of the soil samples [21]. DNA-based Actinobacteria have been reported to be involved in SOM decomposition, particularly lignin and chitin, thereby playing important roles in soil C cycling. However, Actinobacteria have also been reported to be more abundant in undisturbed or less disturbed soils [82], enhancing soil structure in nondisturbed systems due to actinomycete hyphae binding soil particles together. $\mathrm{C} / \mathrm{N}$ was identified as the primary driver influencing the actinobacterial GH48 in the soil studied by De Menezes et al. [83]. This is consistent with our study, which found a positive correlation of C/N, POC to active (RNA-based) Actinobacteria but a negative correlation to DNA-based Actinobacteria (Figure 5). These results can be explained by the role of Actinobacteria in the regulation of the soil organic carbon cycle.

Nitrospirae is a key nitrite-oxidizing bacteria capable of nitrification and mostly uncultured [84]. In this research, the highest abundance of Nitrospirae was found in CK, showing significant correlation with soil $\mathrm{pH}$ and $\mathrm{C} / \mathrm{N}$, consistent with previous reports indicating that Nitrospirae was more abundant in soils with no amendment [65]. They also have been characterized as microbial K-strategists adapted to low substrate concentrations typical of unfertilized soils [84]. The addition of fertilizers was investigated to decrease the abundance of these microbial taxa in this study; however, it was higher with inorganic $\mathrm{N}$ fertilizer addition than with OM addition, which supports a previous report [85].

\subsection{Specific Bacterial Taxa in the OM-Fertilized Treatment Compared with Other Treatments}

Long-term OM input decreased the overall RNA-based bacterial diversity but increased the abundance of some specific species. Previous results showed no significant influences of $\mathrm{N}$ fertilization on bacterial diversity, however, did significantly affect the 
relative abundances within communities $[71,86]$. In addition, organic amendments affected soil bacterial activity thereby changed their structure [87]. In our research, higher relative abundance of some taxa in DM lowered the $\alpha$-diversity in both DNA- and RNA-based bacteria. The RNA-based bacterial class Bacilli was noticeably active in the DM treatment (Figure 3b, Table S3). Previously, this class was exclusively investigated in alkaline soils due to higher SOM [14]. RNA-based Bacilli were found to have a positive relationship with available phosphorus (Olsen-P, Figure S3), indicating that increased levels of RNA-based Bacilli in the arable alkaline soil of the NCP can enhance soil Olsen-P as well as the contents of alkaline phosphatase and naphthol-AS-biphosphate [14], in turn, increasing the crop yield and microbial metabolism to improve soil fertility [14,88]. Bacillus species are known to provide a range of benefits when present in the rhizosphere of growing crops, because they can solubilize soil $\mathrm{P}$, making it available for plant uptake [14]. In conclusion, the relative dominance of Bacilli in DM treatment suggests that this taxon is of great importance to enhance the soil fertility and crop growth in agroecosystems fertilized with organic manure $[14,89]$.

\section{Conclusions}

The diversity and relative abundances of RNA-based bacterial communities differed from those derived from DNA, with the taxa of the DM treatment particularly standing out with a significantly different diversity and relative abundance of RNA-based bacteria. In soils established under 27-year fertilization regimes, lower relative abundance of DNA-based community were investigated and several RNA-based bacteria were found exclusively. This demonstrates that DNA-based amplicon sequencing and RNA-based sequencing reveal significantly different features. For both DNA- and RNA-based taxa, Bacteroidetes and Firmicutes phyla were closely related to POC, Olsen-P, and total N; however, Acidobacteria, Planctomycetes, Verrucomicrobia, Nitrospirae, and Cyanobacteria phyla showed significantly positive correlations with soil $\mathrm{pH}$ and LFOC. Furthermore, the DNAbased Proteobacteria showed negative trends against the RNA-based Proteobacteria. Glycan biosynthesis and metabolism were mainly detected in the DNA samples, which had a positive relationship with LFOC. Xenobiotic biodegradation and metabolism, amino acid metabolism, and terpenoid and polyketide metabolism were relatively higher in the RNA samples and displayed a positive relationship with POC. The high active (RNA-based) abundance of the class Bacilli under higher OM input rates confirms that this taxon is highly important for decomposition in systems that rely on organic matter additions for fertility.

Supplementary Materials: The following are available online at https:/ / www.mdpi.com/article/10.3 390/agronomy11122425/s1, Figure S1: Heat map showing the relative abundance (Log2-transformed) of the top 30 classes from each treatment (a total of 71 classes), Figure S2. Relative abundance of predicted genes from the metagenome related to KEGG pathways at level 1 and 2, Figure S3. Redundancy analysis (RDA) diagram illustrating the relationship between the total (a) and active (b) bacterial community structure at class level from different long-term fertility treatments and environmental variables (TOC, TN, TP, Olsen- $\mathrm{P}, \mathrm{NO}_{3}{ }^{-}-\mathrm{N}$, Available $\mathrm{K}, \mathrm{C} / \mathrm{N}$, and $\mathrm{pH}$ ), Table S1: Effects of long-term fertilization regimes on soil chemical properties under a wheat-maize rotation in China (0-20cm), Table S2: Proportions (\%) of soil bacterial communities at phylum level based on 16S rDNA (-D) and rRNA (-R) sequencing for each fertility treatment, Table S3: Proportions (\%) of soil bacterial communities at class level based on $16 \mathrm{~S}$ rDNA (-D) and rRNA (-R) sequencing for each fertility treatment.

Author Contributions: Conceptualization, J.L. and X.Y.; software, J.L.; data curation, Y.W.; writingoriginal draft preparation, J.L.; writing - review and editing, Y.W.; supervision, X.Y.; funding acquisition, X.Y. All authors have read and agreed to the published version of the manuscript.

Funding: This research was funded by the Central Public-interest Scientific Institution Basal Research Fund (No. Y2020XK21) and and the National Natural Science Foundation of China (NSFC No. 31872177). 
Acknowledgments: We thank Julia Cooper, School of Natural and Environmental Sciences, Newcastle University, UK, for improving this manuscript. This manuscript is in memory of Zhi'an Lin who established this long-term fertilizer trial.

Conflicts of Interest: The authors declare no conflict of interest.

\section{References}

1. Pretty, J.; Bharucha, Z.P. Sustainable intensification in agricultural systems. Ann. Bot. 2014, 114, 1571-1596. [CrossRef] [PubMed]

2. Chen, X.; Cui, Z.; Fan, M.; Vitousek, P.; Zhao, M.; Ma, W.; Wang, Z.; Zhang, W.; Yan, X.; Yang, J.; et al. Producing more grain with lower environmental costs. Nature 2014, 514, 486-489. [CrossRef] [PubMed]

3. Luo, G.; Li, L.; Friman, V.-P.; Guo, J.; Guo, S.; Shen, Q.; Ling, N. Organic amendments increase crop yields by improving microbe-mediated soil functioning of agroecosystems: A meta-analysis. Soil Biol. Biochem. 2018, 124, 105-115. [CrossRef]

4. Van Diepeningen, A.D.; de Vos, O.J.; Korthals, G.W.; van Bruggen, A.H. Effects of organic versus conventional management on chemical and biological parameters in agricultural soils. Appl. Soil Ecol. 2006, 31, 120-135. [CrossRef]

5. Orr, C.H.; James, A.; Leifert, C.; Cooper, J.M.; Cummings, S.P. Diversity and activity of free-living nitrogen-fixing bacteria and total bacteria in organic and conventionally managed soils. Appl. Environ. Microbiol. 2011, 77, 911-919. [CrossRef]

6. Chadwick, D.; Wei, J.; Yan'an, T.; Guanghui, Y.; Qirong, S.; Qing, C. Improving manure nutrient management towards sustainable agricultural intensification in China. Agric. Ecosyst. Environ. 2015, 209, 34-46. [CrossRef]

7. Chen, Q.L.; Ding, J.; Zhu, D.; Hu, H.W.; Delgado Baquerizo, M.; Ma, Y.B.; He, J.Z.; Zhu, Y.G. Rare microbial taxa as the major drivers of ecosystem multifunctionality in long-term fertilized soils. Soil Biol. Biochem. 2020, 141, 107686. [CrossRef]

8. Sradnick, A.; Murugan, R.; Oltmanns, M.; Raupp, J.; Joergensen, R.G. Changes in functional diversity of the soil microbial community in a heterogeneous sandy soil after long-term fertilization with cattle manure and mineral fertilizer. Appl. Soil Ecol. 2013, 63, 23-28. [CrossRef]

9. Liu, J.; Shu, A.J.; Song, W.F.; Shi, W.C.; Li, M.C.; Zhang, W.X.; Li, Z.Z.; Liu, G.R.; Yuan, F.S.; Zhang, S.X.; et al. Long-term organic fertilizer substitution increases rice yield by improving soil properties and regulating soil bacteria. Geoderma 2021, $404,115287$. [CrossRef]

10. Orr, C.H.; Stewart, C.J.; Leifert, C.; Cooper, J.M.; Cummings, S.P. Effect of crop management and sample year on abundance of soil bacterial communities in organic and conventional cropping systems. J. Appl. Microbiol. 2015, 119, 208-214. [CrossRef]

11. Dai, Z.; Su, W.; Chen, H.; Barberán, A.; Zhao, H.; Yu, M.; Yu, L.; Brookes, P.C.; Schadt, C.W.; Chang, S.X.; et al. Long-term nitrogen fertilization decreases bacterial diversity and favors the growth of Actinobacteria and Proteobacteria in agro-ecosystems across the globe. Glob. Chang. Biol. 2018, 24, 3452-3461. [CrossRef] [PubMed]

12. Huang, R.; McGrath, S.P.; Hirsch, P.R.; Clark, I.M.; Storkey, J.; Wu, L.; Zhou, J.; Liang, Y. Plant-microbe networks in soil are weakened by century-long use of inorganic fertilizers. Microb. Biotechnol. 2019, 12, 1464-1475. [CrossRef] [PubMed]

13. Ling, N.; Sun, Y.; Ma, J.; Guo, J.; Zhu, P.; Peng, C.; Yu, G.; Ran, W.; Guo, S.; Shen, Q. Response of the bacterial diversity and soil enzyme activity in particle-size fractions of Mollisol after different fertilization in a long-term experiment. Biol. Fertil. Soils 2014, 50, 901-911. [CrossRef]

14. Feng, Y.; Chen, R.; Hu, J.; Fei, Z.; Wang, J.; Chu, H.; Zhang, J.; Dolfing, J.; Lin, X. Bacillus asahii comes to the fore in organic manure fertilized alkaline soils. Soil Biol. Biochem. 2015, 81, 186-194. [CrossRef]

15. Wang, W.; Wang, H.; Feng, Y.; Wang, L.; Xiao, X.; Xi, Y.; Luo, X.; Sun, R.; Ye, X.; Huang, Y.; et al. Consistent responses of the microbial community structure to organic farming along the middle and lower reaches of the Yangtze River. Sci. Rep. 2016, 6, 35046. [CrossRef]

16. Bonanomi, G.; De Filippis, F.; Cesarano, G.; La Storia, A.; Ercolini, D.; Scala, F. Organic farming induces changes in soil microbiota that affect agro-ecosystem functions. Soil Biol. Biochem. 2016, 103, 327-336. [CrossRef]

17. Cookson, W.R.; Abaye, D.A.; Marschner, P.; Murphy, D.V.; Stockdale, E.A.; Goulding, K.W.T. The contribution of soil organic matter fractions to carbon and nitrogen mineralization and microbial community size and structure. Soil Biol. Biochem. 2005, 37, 1726-1737. [CrossRef]

18. Ramírez, P.B.; Fuentes-Alburquenque, S.; Díez, B.; Vargas, I.; Bonilla, C.A. Soil microbial community responses to labile organic carbon fractions in relation to soil type and land use along a climate gradient. Soil Biol. Biochem. 2020, 141, 107692. [CrossRef]

19. Li, J.; Cooper, J.M.; Lin, Z.A.; Li, Y.; Yang, X.; Zhao, B. Soil microbial community structure and function are significantly affected by long-term organic and mineral fertilization regimes in the North China Plain. Appl. Soil Ecol. 2015, 96, 75-87. [CrossRef]

20. Tian, J.; Lou, Y.; Gao, Y.; Fang, H.; Liu, S.; Xu, M.; Blagodatskaya, E.; Kuzyakov, Y. Response of soil organic matter fractions and composition of microbial community to long-term organic and mineral fertilization. Biol. Fertil. Soils 2017, 53, 523-532. [CrossRef]

21. Gremion, F.; Chatzinotas, A.; Harms, H. Comparative 16S rDNA and 16S rRNA sequence analysis indicates that Actinobacteria might be a dominant part of the metabolically active bacteria in heavy metal-contaminated bulk and rhizosphere soil. Environ. Microbiol. 2003, 5, 896-907. [CrossRef] [PubMed]

22. Toju, H.; Peay, K.G.; Yamamichi, M.; Narisawa, K.; Hiruma, K.; Naito, K.; Fukuda, S.; Ushio, M.; Nakaoka, S.; Onoda, Y.; et al. Core microbiomes for sustainable agroecosystems. Nat. Plants 2018, 4, 247-257. [CrossRef]

23. Graham, E.B.; Wieder, W.R.; Leff, J.W.; Weintraub, S.R.; Townsend, A.R.; Cleveland, C.C.; Philippot, L.; Nemergut, D.R. Do we need to understand microbial communities to predict ecosystem function? A comparison of statistical models of nitrogen cycling processes. Soil Biol. Biochem. 2014, 68, 279-282. [CrossRef] 
24. Widder, S.; Allen, R.; Pfeiffer, T.; Curtis, T.; Wiuf, C.; Sloan, W.; Cordero, O.; Brown, S.; Momeni, B.; Shou, W.; et al. Challenges in microbial ecology: Building predictive understanding of community function and dynamics. ISME J. 2016, 10, 2557-2568. [CrossRef]

25. Cardoso, D.C.; Sandionigi, A.; Cretoiu, M.S.; Casiraghi, M.; Stal, L.; Bolhuis, H. Comparison of the active and resident community of a coastal microbial mat. Sci. Rep. 2017, 7, 2969. [CrossRef] [PubMed]

26. Che, R.; Deng, Y.; Wang, F.; Wang, W.; Xu, Z.; Wang, Y.; Cui, X. 16S rRNA-based bacterial community structure is a sensitive indicator of soil respiration activity. J. Soil Sediments 2015, 15, 1987-1990. [CrossRef]

27. Freedman, Z.B.; Romanowicz, K.J.; Upchurch, R.A.; Zak, D.R. Differential responses of total and active soil microbial communities to long-term experimental N deposition. Soil Biol. Biochem. 2015, 90, 275-282. [CrossRef]

28. Che, R.; Deng, Y.; Wang, W.; Rui, Y.; Zhang, J.; Tahmasbian, I.; Tang, L.; Wang, S.; Wang, Y.; Xu, Z.; et al. Long-term warming rather than grazing significantly changed total and active soil procaryotic community structures. Geoderma 2018, 316, 1-10. [CrossRef]

29. Kuramae, E.E.; Verbruggen, E.; Hillekens, R.; de Hollander, M.; Röling, W.F.M.; van der Heijden, M.G.A.; Kowalchuk, G.A. Tracking Fungal Community Responses to Maize Plants by DNA- and RNA-based Pyrosequencing. PLoS ONE 2013, 8, e69973. [CrossRef]

30. Baldrian, P.; Kolarik, M.; Stursova, M.; Kopecky, J.; Valaskova, V.; Vetrovsky, T.; Zifcakova, L.; Snajdr, J.; Ridl, J.; Vlcek, C.; et al. Active and total microbial communities in forest soil are largely different and highly stratified during decomposition. ISME $J$. 2012, 6, 248-258. [CrossRef]

31. Wang, J.; Wang, E.; Yang, X.; Zhang, F.; Yin, H. Increased yield potential of wheat-maize cropping system in the North China Plain by climate change adaptation. Clim. Chang. 2012, 113, 825-840. [CrossRef]

32. Shi, Y.; Li, Y.; Xiang, X.; Sun, R.; Yang, T.; He, D.; Zhang, K.; Ni, Y.; Zhu, Y.-G.; Adams, J.M.; et al. Spatial scale affects the relative role of stochasticity versus determinism in soil bacterial communities in wheat fields across the North China Plain. Microbiome 2018, 6, 27. [CrossRef]

33. Li, J.; Wen, Y.; Li, X.; Li, Y.; Yang, X.; Lin, Z.; Song, Z.; Cooper, J.M.; Zhao, B. Soil labile organic carbon fractions and soil organic carbon stocks as affected by long-term organic and mineral fertilization regimes in the North China Plain. Soil Tillage Res. 2018, 175, 281-290. [CrossRef]

34. Mettel, C.; Kim, Y.; Shrestha, P.M.; Liesack, W. Extraction of mRNA from Soil. Appl. Environ. Microbiol. 2010, 76, 5995-6000. [CrossRef] [PubMed]

35. Cai, Y.; Zheng, Y.; Bodelier, P.L.E.; Conrad, R.; Jia, Z. Conventional methanotrophs are responsible for atmospheric methane oxidation in paddy soils. Nat. Commun. 2016, 7, 11728. [CrossRef] [PubMed]

36. Amato, K.R.; Yeoman, C.J.; Kent, A.; Righini, N.; Carbonero, F.; Estrada, A.; Rex Gaskins, H.; Stumpf, R.M.; Yildirim, S.; Torralba, M.; et al. Habitat degradation impacts black howler monkey (Alouatta pigra) gastrointestinal microbiomes. ISME J. 2013, 7, 1344-1353. [CrossRef]

37. Schloss, P.D.; Westcott, S.L.; Ryabin, T.; Hall, J.R.; Hartmann, M.; Hollister, E.B.; Lesniewski, R.A.; Oakley, B.B.; Parks, D.H.; Robinson, C.J.; et al. Introducing mothur: Open-Source, Platform-Independent, Community-Supported Software for Describing and Comparing Microbial Communities. Appl. Environ. Microbiol. 2009, 75, 7537-7541. [CrossRef]

38. Sun, L.; Xun, W.B.; Huang, T.; Zhang, G.S.; Gao, J.S.; Ran, W.; Li, D.C.; Shen, Q.R.; Zhang, R.F. Alteration of the soil bacterial community during parent material maturation driven by different fertilization treatments. Soil Biol. Biochem. 2016, 96, 207-215. [CrossRef]

39. Lozupone, C.; Lladser, M.E.; Knights, D.; Stombaugh, J.; Knight, R. UniFrac: An effective distance metric for microbial community comparison. ISME J. 2011, 5, 169-172. [CrossRef] [PubMed]

40. Zhou, J.Z.; Deng, Y.; Luo, F.; He, Z.L.; Tu, Q.C.; Zhi, X.Y. Functional molecular ecological networks. mBio 2010, 1, 10. [CrossRef]

41. Deng, Y.; Jiang, Y.H.; Yang, Y.; He, Z.; Luo, F.; Zhou, J. Molecular ecological network analyses. BMC Bioinform. 2012, 13, 113-132. [CrossRef] [PubMed]

42. Ling, N.; Zhu, C.; Xue, C.; Chen, H.; Duan, Y.; Peng, C.; Guo, S.; Shen, Q. Insight into how organic amendments can shape the soil microbiome in long-term field experiments as revealed by network analysis. Soil Biol. Biochem. 2016, 99, 137-149. [CrossRef]

43. Ogilvie, L.A.; Hirsch, P.R.; Johnston, A.W. Bacterial diversity of the Broadbalk 'classical'winter wheat experiment in relation to long-term fertilizer inputs. Microb. Ecol. 2008, 56, 525-537. [CrossRef] [PubMed]

44. Zhao, J.; Ni, T.; Li, Y.; Xiong, W.; Ran, W.; Shen, B.; Shen, Q.; Zhang, R. Responses of bacterial communities in arable soils in a rice-wheat cropping system to different fertilizer regimes and sampling times. PLoS ONE 2014, 9, e85301. [CrossRef] [PubMed]

45. Janssen, P.H. Identifying the dominant soil bacterial taxa in libraries of $16 \mathrm{~S}$ rRNA and $16 \mathrm{~S}$ rRNA genes. Appl. Environ. Microbiol. 2006, 72, 1719-1728. [CrossRef] [PubMed]

46. Schloss, P.D.; Handelsman, J. Toward a census of bacteria in soil. PLoS Comput. Biol. 2006, 2, 786-793. [CrossRef]

47. Ding, J.; Jiang, X.; Ma, M.; Zhou, B.; Guan, D.; Zhao, B.; Zhou, J.; Cao, F.; Li, L.; Li, J. Effect of 35 years inorganic fertilizer and manure amendment on structure of bacterial and archaeal communities in black soil of northeast China. Appl. Soil Ecol. 2016, 105, 187-195. [CrossRef]

48. Chu, H.; Fierer, N.; Lauber, C.L.; Caporaso, J.G.; Knight, R.; Grogan, P. Soil bacterial diversity in the Arctic is not fundamentally different from that found in other biomes. Environ. Microbiol. 2010, 12, 2998-3006. [CrossRef] 
49. Žif̌ćáková, L.; Větrovský, T.; Howe, A.; Baldrian, P. Microbial activity in forest soil reflects the changes in ecosystem properties between summer and winter. Environ. Microbiol. 2016, 18, 288-301. [CrossRef]

50. Delgado Baquerizo, M.; Oliverio, A.M.; Brewer, T.E.; Benavent-González, A.; Eldridge, D.J.; Bardgett, R.D.; Maestre, F.T.; Singh, B.K.; Fierer, N. A global atlas of the dominant bacteria found in soil. Science 2018, 359, 320-325. [CrossRef]

51. Wu, T.; Chellemi, D.; Graham, J.; Martin, K.; Rosskopf, E. Comparison of soil bacterial communities under diverse agricultural land management and crop production practices. Microb. Ecol. 2008, 55, 293-310. [CrossRef]

52. O'Brien, S.L.; Gibbons, S.M.; Owens, S.M.; Hampton-Marcell, J.; Johnston, E.R.; Jastrow, J.D.; Gilbert, J.A.; Meyer, F.; Antonopoulos, D.A. Spatial scale drives patterns in soil bacterial diversity. Environ. Microbiol. 2016, 18, 2039-2051. [CrossRef]

53. Liang, Y.; Zhang, Y.; Zhou, C.; Li, H.; Kang, X.; Wang, L.; Song, J.; Jiao, N. Cumulative impact of long-term intensive mariculture on total and active bacterial communities in the core sediments of the Ailian Bay, North China. Sci. Total Environ. 2019, 691, 1212-1224. [CrossRef]

54. Gill, A.S.; Lee, A.; McGuire, K.L. Phylogenetic and functional diversity of total (DNA) and expressed (RNA) bacterial communities in urban green infrastructure bioswale soils. Appl. Environ. Microbiol. 2017, 83, e00287-17. [CrossRef] [PubMed]

55. Xiong, W.; Li, R.; Ren, Y.; Liu, C.; Zhao, Q.; Wu, H.; Jousset, A.; Shen, Q. Distinct roles for soil fungal and bacterial communities associated with the suppression of vanilla Fusarium wilt disease. Soil Biol. Biochem. 2017, 107, 198-207. [CrossRef]

56. Langille, M.G.; Zaneveld, J.; Caporaso, J.G.; McDonald, D.; Knights, D.; Reyes, J.A.; Clemente, J.C.; Burkepile, D.E.; Thurber, R.L.V.; Knight, R.; et al. Predictive functional profiling of microbial communities using 16S rRNA marker gene sequences. Nat. Biotechnol. 2013, 31, 814-821. [CrossRef]

57. Razanamalala, K.; Razafimbelo, T.; Maron, P.A.; Ranjard, L.; Chemidlin, N.; Lelièvre, M.; Dequiedt, S.; Ramaroson, V.H.; Marsden, C.; Becquer, T.; et al. Soil microbial diversity drives the priming effect along climate gradients: A case study in Madagascar. ISME J. 2017, 12, 451-462. [CrossRef]

58. Yi, J.; Wu, H.Y.; Wu, J.; Deng, C.Y.; Zheng, R.; Chao, Z. Molecular phylogenetic diversity of Bacillus community and its temporal-spatial distribution during the swine manure of composting. Appl. Microbiol. Biotechnol. 2012, 93, 411-421. [CrossRef] [PubMed]

59. Jones, S.; Lennon, J. Dormancy contributes to the maintenance of microbial diversity. Proc. Natl. Acad. Sci. USA 2010, 107, 5881-5886. [CrossRef]

60. McCarren, J.; Becker, J.W.; Repeta, D.J.; Shi, Y.; Young, C.R.; Malmstrom, R.R.; Chisholm, S.W.; DeLong, E.F. Microbial community transcriptomes reveal microbes and metabolic pathways associated with dissolved organic matter turnover in the sea. Proc. Natl. Acad. Sci. USA 2010, 107, 16420-16427. [CrossRef] [PubMed]

61. Hugenholtz, P.; Goebel, B.M.; Pace, N.R. Impact of culture-independent studies on the emerging phylogenetic view of bacterial diversity. J. Bacteriol. 1998, 180, 4765-4774. [CrossRef]

62. Jones, R.T.; Robeson, M.S.; Lauber, C.L.; Hamady, M.; Knight, R.; Fierer, N. A comprehensive survey of soil acidobacterial diversity using pyrosequencing and clone library analyses. ISME J. 2009, 3, 442-453. [CrossRef]

63. Cederlund, H.; Wessén, E.; Enwall, K.; Jones, C.M.; Juhanson, J.; Pell, M.; Philippot, L.; Hallin, S. Soil carbon quality and nitrogen fertilization structure bacterial communities with predictable responses of major bacterial phyla. Appl. Soil Ecol. 2014, 84, 62-68. [CrossRef]

64. Birrer, S.C.; Dafforn, K.A.; Simpson, S.L.; Kelaher, B.P.; Potts, J.; Scanes, P.; Johnston, E.L. Interactive effects of multiple stressors revealed by sequencing total (DNA) and active (RNA) components of experimental sediment microbial communities. Sci. Total Environ. 2018, 637-638, 1383-1394. [CrossRef]

65. Eo, J.; Park, K.C. Long-term effects of imbalanced fertilization on the composition and diversity of soil bacterial community. Agric. Ecosyst. Environ. 2016, 231, 176-182. [CrossRef]

66. Davis, K.E.R.; Sangwan, P.; Janssen, P.H. Acidobacteria, Rubrobacteridae and Chloroflexi are abundant among very slow-growing and mini-colony-forming soil bacteria. Environ. Microbiol. 2011, 13, 798-805. [CrossRef] [PubMed]

67. Hester, E.R.; Harpenslager, S.F.; van Diggelen, J.M.H.; Lamers, L.L.; Jetten, M.S.M.; Lüke, C.; Lücker, S.; Welte, C.U. Linking nitrogen load to the structure and function of wetland soil and rhizosphere microbial communities. Msystems 2018, 3, e00214-17. [CrossRef] [PubMed]

68. Xun, W.; Zhao, J.; Xue, C.; Zhang, G.; Ran, W.; Wang, B.; Shen, Q.; Zhang, R. Significant alteration of soil bacterial communities and organic carbon decomposition by different long-term fertilization management conditions of extremely low-productivity arable soil in South China. Environ. Microbiol. 2016, 18, 1907-1917. [CrossRef]

69. Zarb, J.; Ghorbani, R.; Koocheki, A.; Leifert, C. The importance of microorganisms in organic agriculture. Outlooks Pest Manag. 2005, 16, 52-55. [CrossRef]

70. Geisseler, D.; Scow, K.M. Long-term effects of mineral fertilizers on soil microorganisms-A review. Soil Biol. Biochem. 2014, 75, 54-63. [CrossRef]

71. Fierer, N.; Leff, J.W.; Adams, B.J.; Nielsen, U.N.; Bates, S.T.; Lauber, C.L.; Owens, S.; Gilbert, J.A.; Wall, D.H.; Caporaso, J.G. Cross-biome metagenomic analyses of soil microbial communities and their functional attributes. Proc. Natl. Acad. Sci. USA 2012, 109, 21390-21395. [CrossRef]

72. Zhang, L.; Shi, N.; Fan, J.; Wang, F.; George, T.S.; Feng, G. Arbuscular mycorrhizal fungi stimulate organic phosphate mobilization associated with changing bacterial community structure under field conditions. Environ. Microbiol. 2018, 20, 2639-2651. [CrossRef] 
73. Wang, C.; Liu, D.; Bai, E. Decreasing soil microbial diversity is associated with decreasing microbial biomass under nitrogen addition. Soil Biol. Biochem. 2018, 120, 126-133. [CrossRef]

74. Rousk, J.; Bååth, E.; Brookes, P.C.; Lauber, C.L.; Lozupone, C.; Caporaso, J.G.; Knight, R.; Fierer, N. Soil bacterial and fungal communities across a pH gradient in an arable soil. ISME J. 2010, 4, 1340-1351. [CrossRef] [PubMed]

75. Sun, R.B.; Zhang, X.X.; Guo, X.S.; Wang, D.Z.; Chu, H.Y. Bacterial diversity in soils subjected to long-term chemical fertilization can be more stably maintained with the addition of livestock manure than wheat straw. Soil Biol. Biochem. 2015, 88, 9-18. [CrossRef]

76. Nicol, G.W.; Leininger, S.; Schleper, C.; Prosser, J.I. Influence of soil pH on the diversity, abundance and transcriptional activity of ammonia oxidizing archaea and bacteria. Environ. Microbiol. 2008, 10, 2966-2978. [CrossRef] [PubMed]

77. Lauber, C.L.; Hamady, M.; Knight, R.; Fierer, N. Pyrosequencing-based assessment of soil pH as a predictor of soil bacterial community structure at the continental scale. Appl. Environ. Microbiol. 2009, 75, 5111-5120. [CrossRef]

78. Zhou, J.; Guan, D.; Zhou, B.; Zhao, B.; Ma, M.; Qin, J.; Jiang, X.; Chen, S.; Cao, F.; Shen, D.; et al. Influence of 34-years of fertilization on bacterial communities in an intensively cultivated black soil in northeast China. Soil Biol. Biochem. 2015, 90, 42-51. [CrossRef]

79. Zhou, J.; Jiang, X.; Wei, D.; Zhao, B.S.; Ma, M.C.; Chen, S.F.; Cao, F.M.; Shen, D.L.; Guan, D.W.; Li, J. Consistent effects of nitrogen fertilization on soil bacterial communities in black soils for two crop seasons in China. Sci. Rep. 2017, 7, 3267. [CrossRef]

80. Wang, J.; Xue, C.; Song, Y.; Wang, L.; Huang, Q.; Shen, Q. Wheat and Rice Growth Stages and Fertilization Regimes Alter Soil Bacterial Community Structure, But Not Diversity. Front. Microbiol. 2016, 7, 1207. [CrossRef]

81. Liu, X.; Cong, J.; Lu, H.; Xue, Y.; Wang, X.; Li, D.; Zhang, Y. Community structure and elevational distribution pattern of soil Actinobacteria in alpine grasslands. Acta Ecol. Sin. 2017, 37, 213-218. [CrossRef]

82. Acosta-Martínez, V.; Dowd, S.; Sun, Y.; Allen, V. Tag-encoded pyrosequencing analysis of bacterial diversity in a single soil type as affected by management and land use. Soil Biol. Biochem. 2008, 40, 2762-2770. [CrossRef]

83. De Menezes, A.B.; Prendergast-Miller, M.T.; Poonpatana, P.; Farrell, M.; Bissett, A.; Macdonald, L.M.; Toscas, P.; Richardson, A.E.; Thrall, P.H. C/N ratio drives soil actinobacterial cellobiohydrolase gene diversity. Appl. Environ. Microbiol. 2015, 81, $3016-3028$. [CrossRef] [PubMed]

84. Daims, H.; Lebedeva, E.V.; Pjevac, P.; Han, P.; Herbold, C.; Albertsen, M.; Jehmlich, N.; Palatinszky, M.; Vierheilig, J.; Bulaev, A.; et al. Complete nitrification by Nitrospira bacteria. Nature 2015, 528, 504-509. [CrossRef]

85. Coolon, J.; Jones, K.; Todd, T.; Blair, J.; Herman, M. Long-Term Nitrogen Amendment Alters the Diversity and Assemblage of Soil Bacterial Communities in Tallgrass Prairie. PLoS ONE 2013, 8, e67884. [CrossRef] [PubMed]

86. Ramirez, K.S.; Craine, J.M.; Fierer, N. Consistent effects of nitrogen amendments on soil microbial communities and processes across biomes. Glob. Chang. Biol. 2012, 18, 1918-1927. [CrossRef]

87. Leite, M.F.A.; Yao, P.; Bloem, J.; Berge, H.T.; Kuramae, E.E. Organic nitrogen rearranges both structure and activity of the soil-borne microbial seedbank. Sci. Rep. 2017, 7, 42634. [CrossRef]

88. Lin, X.; Feng, Y.; Zhang, H.; Chen, R.; Wang, J.; Zhang, J.; Chu, H. Long-term balanced fertilization decreases arbuscular mycorrhizal fungal diversity in an arable soil in North China revealed by 454 pyrosequencing. Environ. Sci. Technol. 2012, 46, 5764-5771. [CrossRef]

89. Banerjee, S.; Schlaeppi, K.; van der Heijden, M.G.A. Keystone taxa as drivers of microbiome structure and functioning. Nat. Rev. Microbiol. 2018, 16, 567-576. [CrossRef] [PubMed] 